\title{
Mid-21st century air quality at the urban scale under the influence of changed climate and emissions - case studies for Paris and Stockholm
}

\author{
Konstantinos Markakis ${ }^{1}$, Myrto Valari ${ }^{1}$, Magnuz Engardt ${ }^{2}$, Gwendoline Lacressonniere ${ }^{3}$, Robert Vautard $^{3}$, and \\ Camilla Andersson ${ }^{2}$ \\ ${ }^{1}$ Laboratoire de Meteorologie Dynamique, IPSL Laboratoire CEA/CNRS/UVSQ, Ecole Polytechnique, \\ 91128 Palaiseau CEDEX, France \\ ${ }^{2}$ Swedish Meteorological and Hydrological Institute, 60176 Norrköping, Sweden \\ ${ }^{3}$ Laboratoire des Sciences du Climat et de l'Environnement, IPSL Laboratoire CEA/CNRS/UVSQ, Orme des Merisiers, \\ 91191 Gif-sur-Yvette CEDEX, France
}

Correspondence to: Konstantinos Markakis (konstantinos.markakis@lmd.polytechnique.fr)

Received: 6 July 2015 - Published in Atmos. Chem. Phys. Discuss.: 7 October 2015

Revised: 26 January 2016 - Accepted: 28 January 2016 - Published: 18 February 2016

\begin{abstract}
Ozone, $\mathrm{PM}_{10}$ and $\mathrm{PM}_{2.5}$ concentrations over Paris, France and Stockholm, Sweden were modelled at 4 and $1 \mathrm{~km}$ horizontal resolutions respectively for the present and 2050 periods employing decade-long simulations. We account for large-scale global climate change (RCP-4.5) and fine-resolution bottom-up emission projections developed by local experts and quantify their impact on future pollutant concentrations. Moreover, we identify biases related to the implementation of regional-scale emission projections by comparing modelled pollutant concentrations between the fine- and coarse-scale simulations over the study areas. We show that over urban areas with major regional contribution (e.g. the city of Stockholm) the bias related to coarse-scale projections may be significant and lead to policy misclassification. Our results stress the need to better understand the mechanism of bias propagation across the modelling scales in order to design more successful local-scale strategies. We find that the impact of climate change is spatially homogeneous in both regions, implying strong regional influence. The climate benefit for ozone (daily mean and maximum) is up to $-5 \%$ for Paris and $-2 \%$ for Stockholm city. The climate benefit on $\mathrm{PM}_{2.5}$ and $\mathrm{PM}_{10}$ in Paris is between -5 and $-10 \%$, while for Stockholm we estimate mixed trends of up to $3 \%$ depending on season and size class. In Stockholm, emission mitigation leads to concentration reductions up to $15 \%$ for daily mean and maximum ozone and $20 \%$ for PM. Through a sensitivity analysis we show that this re-
\end{abstract}

sponse is entirely due to changes in emissions at the regional scale. On the contrary, over the city of Paris (VOC-limited photochemical regime), local mitigation of $\mathrm{NO}_{x}$ emissions increases future ozone concentrations due to ozone titration inhibition. This competing trend between the respective roles of emission and climate change, results in an increase in 2050 daily mean ozone by $2.5 \%$ in Paris. Climate and not emission change appears to be the most influential factor for maximum ozone concentration over the city of Paris, which may be particularly interesting from a health impact perspective.

\section{Introduction}

There is a growing body of literature on the projected effects of climate and emission reduction scenarios on future air quality. The published research encompasses an envelope of models and methodologies; up to now global-scale models have been extensively used to study the impact of climate on tropospheric ozone at global or regional scales (Liao et al., 2006; Prather et al., 2003; Szopa and Hauglustaine, 2007), while chemistry transport models (CTMs), having more advanced parametrization of physical and chemical processes, are applied to study selected regions with refined horizontal resolution (Andersson and Engardt, 2010; Colette et al., 
2012, 2013; Katragkou et al., 2011; Langner et al., 2012a; Nolte et al., 2008; Zanis et al., 2011).

Numerical models are used to study future evolution of air quality as they allow the evaluation of the effectiveness of planned strategies to mitigate pollutant concentrations. This is particularly important since it is now well established that elevated concentrations deteriorate human health (Jerrett et al., 2009; Lepeule et al., 2012), while new scientific evidence indicates that pollution is harmful at even lower levels than previously thought (REVIHAAP, 2013). There is an increasing number of studies investigating the health effects of population exposure to specific emission source types such as traffic, industry or biomass burning (REVIHAAP, 2013, and references therein). Although a clear association is not established, there is evidence that living near busy roads substantially increases the total burden of disease attributable to air pollution (Pascal et al., 2013). In Europe, one-third of the urban population resides in areas where the legislated target value for $\mathrm{PM}_{10}$ is exceeded (EEA, 2013).

The fact that today most of the world's (and Europe's) population lives in cities stresses the need to resolve the variability of pollutant concentrations and provide predictions of future air quality at the urban scale (Riahi et al., 2011). Up to now the principal focus of relevant research was solely on the global and regional scales utilizing modelling resolutions of a few hundred (global) to a few tenths (regional) of kilometres. Nevertheless, it has been repeatedly shown that coarse resolutions are inadequate to resolve fine-scale features (Markakis et al., 2014, 2015; Valari and Menut, 2008; Vautard et al., 2007) due to insufficient representation of chemistry and the use of coarse-resolution emission inventories that cannot dissociate the strong emission gradients of the large urban agglomerations from those at surrounding rural areas. There is still practically no information on the climate-air-quality interactions at the urban scale. A reason is the large computational demand in refining model resolution, while maintaining large spatial coverage. Another is the fact that emission scenarios at fine scale are rarely developed, since long-term projections are constrained by the evolution of energy supply and demand, which is a largescale issue. Air quality projections employing locally developed policy are scarce; a first attempt is described in Gidhagen et al. (2012) who developed air quality projections into the near future (2030s) for the greater Stockholm region in Sweden with a high-resolution $(4 \mathrm{~km})$ modelling system. The impacts were assessed in terms of climate and emissions that were constructed by local experts, however the number of meteorological years included was limited and emissions were projected only for the road transport sector. In Markakis et al. (2014) we describe long-term air quality projections (2050) at urban scale utilizing 10-year-long simulations and fine scale features such as high model resolution $(4 \mathrm{~km})$ and an emission inventory developed by local experts for the Ilde-France (IdF; an eight-department area including Paris) region in France.
In the present assessment we implement several improvements compared to the works of Gidhagen et al. (2012) for the Stockholm region and Markakis et al. (2014) for IdF, aiming to improve our knowledge on the climate and pollutants' emissions-driven air quality responses at a refined scale. Here we develop a consistent framework including identical climate and emission scenarios at global and regional scales, horizon of projection (2050), number of simulation years (decade) and pollutants considered (ozone, $\mathrm{PM}_{10}$ and $\mathrm{PM}_{2.5}$ ). We implement a high-resolution modelling grid of $1 \mathrm{~km}$ for Stockholm and $4 \mathrm{~km}$ for the IdF region. Here (in contrast to Markakis et al., 2014) we take into account changes from large-scale global climate and fine-scale local emissions and disentangle their influence in shaping local concentrations at the 2050 horizon. For Stockholm we additionally quantify the contribution of the locally enforced emission reduction plan from that introduced by the panEuropean change in emissions. To describe the future evolution of pollutant emissions at the city scales we rely on highresolution bottom-up projections at the 2030 horizon developed by local experts (instead of 2020 used in Markakis et al., 2014).

Additionally, we employ the coarse applications that have provided the boundary conditions to the fine-scale simulations from which we extract the signal for ozone, $\mathrm{PM}_{10}$ and $\mathrm{PM}_{2.5}$ of future concentration change related to the emission mitigation over the IdF and Stockholm domains. Previous research conducted in IdF (Markakis et al., 2014) indicated a possible overestimation of the ozone concentration response from coarse-resolution applications in areas characterized by VOC-limited conditions. More specifically we (Markakis et al., 2014) have identified opposing signals in the projected maximum ozone concentrations, with the regionalscale application yielding large decreases while the urbanscale sees large increases attributed to the fact that the former implemented top-down coarse-resolution emissions and portrayed Paris under $\mathrm{NO}_{x}$-limited chemistry at present-time conditions, therefore making the city more receptive to forthcoming $\mathrm{NO}_{x}$ emission reductions, compared to the highresolution simulation portraying a VOC-limited chemistry for Paris. Given that coarse inventories lack the integration of local policies, this work advances on the work of Markakis et al. (2014) and Gidhagen et al. (2012) by providing the means to identify the differences arising when finer areas are investigated with the refined information of locally developed emission projections and higher resolution. This can help to answer whether there is an added value in integrating local emission-related policy to larger-scale inventories. Specifically for ozone, in order to facilitate the comparison between the scales, we examine the long-term evolution of chemical regimes by employing chemical regime indicators which are a measure of radical production/loss processes (Beekman and Vautard, 2010; Sillman et al., 2003). 


\section{Materials and methods}

The IdF region is located in north-central France (1.25$3.58^{\circ} \mathrm{E}$ and $47.89-49.45^{\circ} \mathrm{N}$ ) with a population of 11.7 million, more than 2 million of which live in the city of Paris. The area is situated away from the coast and is characterized by uniform and low topography, not exceeding $200 \mathrm{~m}$ above sea level. Stockholm is located in southeastern Sweden, with a population of 1.4 million. Stockholm is located partly on islands where the western coast of the Baltic Sea meets Lake Mälaren. Figure 1 illustrates the modelling domains of the urban-scale simulations over IdF and Stockholm regions and the boundaries of the cities of Paris and Stockholm. Ten-year-long simulations were carried out over each domain to represent present-time (1991-2000) and mid-21st century (2046-2055) air quality.

We note that a cross-city comparison of results is beyond the scope of this study. The two cities are used as illustrative examples of large urban agglomerations that have different origins of influence; Stockholm experiences the dominant contribution of non-local sources while Paris is much more affected by local emissions. We find that in Stockholm, 99 and $74 \%$ of the local ozone and annual $\mathrm{PM}_{2.5}$ concentrations respectively originate from non-local sources. In previous work (Markakis et al., 2014) we show that in Paris ozone chemistry is strongly VOC-limited and ozone concentrations are shaped by local titration. In Markakis et al. (2015) we also show that $\mathrm{PM}_{2.5}$-related air quality in Paris is very sensitive to local emission changes.

\subsection{Regional downscaling of climate and air quality data}

The air-quality simulations for the IdF and Stockholm regions were conducted to support urban-scale health impact assessment under the framework of the ACCEPTED ("Assessment of changing conditions, environmental policies, time-activities, exposure and disease") project. Table 1 summarizes the chain of models and configurations utilized for the two case studies. To derive projections of the main climate drivers over Europe at $0.11^{\circ}$ horizontal resolution (see Giorgi et al., 2012), we used the IPSL-CM5A-MR (Dufresne et al., 2013) global climate model downscaled with the WRF regional climate model (Skamarock and Klemp, 2008) for the IdF region and the EC-EARTH global climate model, downscaled with the RCA4 regional climate model (Jacob et al., 2014; Strandberg et al., 2014) for Stockholm. In total, eight (for present and future) meteorological simulations were implemented in this study.

For both case studies, pollutant concentrations at the global scale were simulated (Szopa et al., 2013) with the LMDz-INCA global model (Hauglustaine et al., 2004) at monthly temporal resolution. The regional downscaling of multi-year pollutant concentration averages though, is done separately for each case study, first over $0.44^{\circ}(\sim 50 \mathrm{~km})$ res-
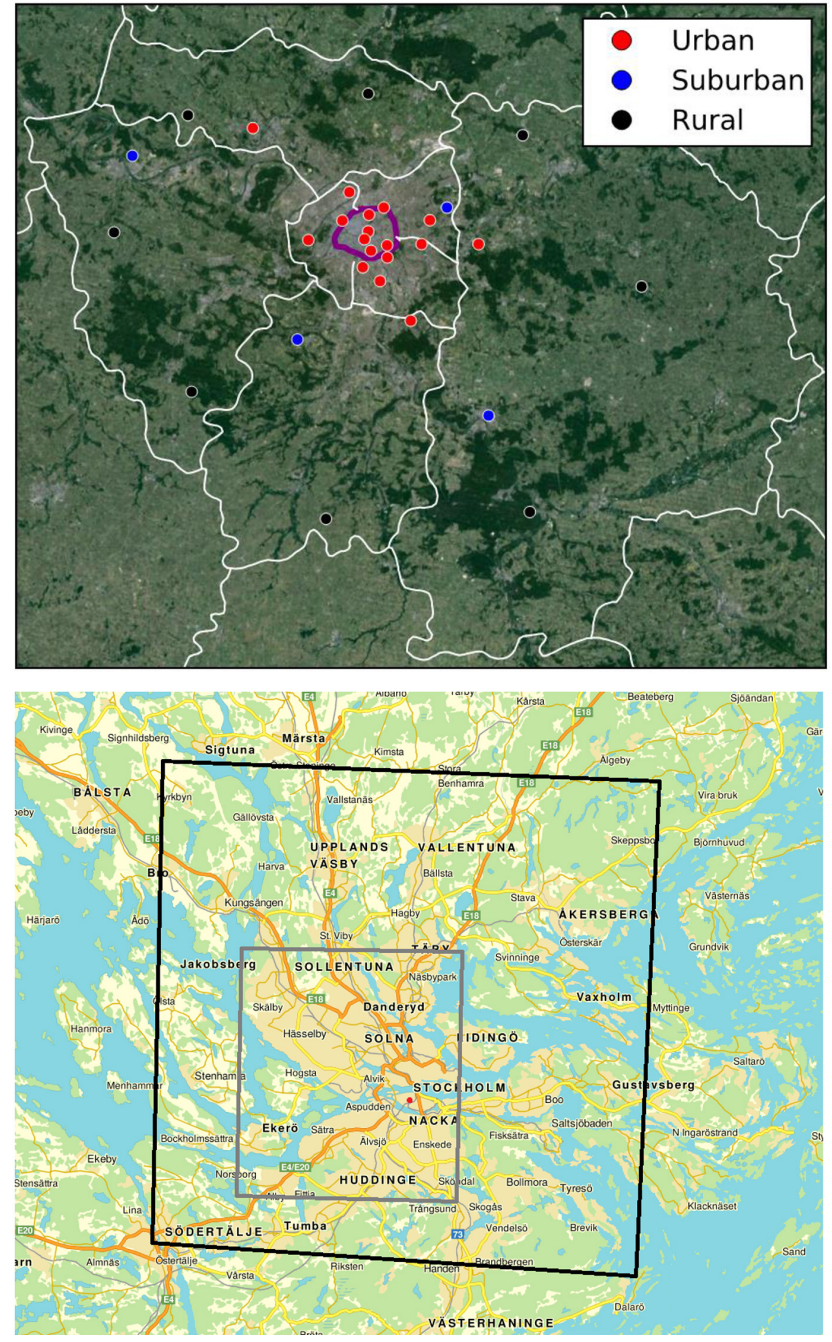

Figure 1. Top panel illustrates the IdF $4 \mathrm{~km}$ resolution modelling domain, with the city of Paris in the centre (area enclosed by the purple line). Circles correspond to sites of the local air quality monitoring network (AIRPARIF) with red for urban, blue for suburban and black for rural. Bottom panel represents the Stockholm $1 \mathrm{~km}$ resolution modelling domain (black outline) with the urban area enclosed in the grey rectangle. The red circle corresponds to the urban monitoring site.

olution grids over Europe and then with a single nest over a $4 \mathrm{~km}$ resolution grid over the IdF region and a two-step nesting over grids of $0.11^{\circ}(\sim 12 \mathrm{~km})$ and $1 \mathrm{~km}$ resolution over Sweden and Stockholm respectively (six simulations in total were conducted at present-day conditions). A thorough presentation of the regional-scale air quality simulations used as boundary conditions for the urban-scale runs are provided in Watson et al. (2015).

Two sets of simulations (for each scale) were conducted at future conditions; in the first case we implement future meteorology along with present-time emissions in order to isolate the effect of climate change whereas in the second case we 
Table 1. Models (and their implemented resolutions) used for the simulations over the study regions.

\begin{tabular}{lllllc}
\hline & \multicolumn{2}{c}{ Climate $^{\mathrm{a}}$} & & \multicolumn{2}{c}{ Air quality $^{\mathrm{b}}$} \\
\cline { 2 - 3 } \cline { 5 - 6 } & IdF & Stockholm & & IdF & Stockholm \\
\hline Global & IPSL-CM5A-MR & EC-EARTH & & & LMDz-INCA \\
& $1.25^{\circ} \times 1.25^{\circ}$ & $1.125^{\circ} \times 1.25^{\circ}$ & & \multicolumn{2}{c}{$3.75^{\circ} \times 1.9^{\circ}$} \\
Regional & WRF, $0.11^{\circ}$ & RCA4, $0.11^{\circ}$ & & CHIMERE, $0.44^{\circ}$ & MATCH, $0.44^{\circ} / 0.11^{\circ}$ \\
Urban & Same as regional & Same as regional & & CHIMERE, $4 \mathrm{~km}$ & MATCH, $1 \mathrm{~km}$ \\
\hline
\end{tabular}

a IPSL-CM5A-MR: Institute Pierre Simon Laplace Climate Model 5A Mid-Resolution, WRF: Weather Research and Forecasting, EC-EARTH: European Centre-Earth, RCA4: Rossby Centre regional atmospheric model. ${ }^{\mathrm{b}}$ LMDz-INCA: Laboratoire de Météorologie Dynamique Zoom- INteraction avec la Chimie et les Aérosols, MATCH: Multi-scale Atmospheric Transport and Chemistry.

utilize future meteorology and projected emissions to quantify the combined effect of climate and emissions change. The signal of emission mitigation alone can be subsequently derived from the concentration difference between the two aforementioned runs (the linearity of this relationship was confirmed for the Stockholm simulations and assumed for the IdF simulations). Finally, only for the Stockholm domain we run an additional test case that allows the quantification of the contribution of emission changes at the regional scale compared to the role of the urban-scale emission mitigation. This is completed using future projections of local emissions for Stockholm but keeping the respective emissions of the regional-scale simulation at present-time levels.

Air quality simulations were conducted with the CHIMERE (Menut et al., 2013) and MATCH (Robertson et al., 1999) CTMs for the IdF and Stockholm regions respectively. CHIMERE is used at both urban and regional scales and it has been benchmarked in a number of model intercomparison experiments (see Menut et al., 2013, and references therein). The MATCH model is applicable to scales from urban to hemispheric and has been extensively used to study the connection between climate change and air quality in Europe (e.g. Andersson and Engardt, 2010; Engardt et al., 2009; Langner et al., 2005, 2012b). Both models are used operationally for emergency preparedness, environmental surveillance and air quality forecasts in France (http://www.prevair.org), Sweden (http://www.smhi.se) and the EU (http://www.macc.eu).

The CHIMERE model includes gas-phase, solid-phase and aqueous chemistry, biogenic emission modelling with the Model of Emissions of Gases and Aerosols from Nature (MEGAN) (Guenther et al., 2006), dust emissions (Menut et al., 2005) and re-suspension (Vautard et al., 2005) modules. Gas-phase chemistry is based on the MELCHIOR mechanism (Lattuati, 1997) and includes more than 300 reactions of 80 gaseous species. CHIMERE treats sulfates, nitrates, ammonium, organic and black carbon, dust and sea-salt. The gas-particle partitioning is treated with ISORROPIA (Nenes et al., 1998). The secondary organic aerosol (SOA) chemistry of CHIMERE is described in Bessagnet et al. (2009).
The MATCH model includes options for data assimilation (e.g. Kahnert, 2008), modules describing aerosol microphysics (Andersson et al., 2015) and ozone- and particleforming photo-chemistry considering $\sim 60$ species (Langner et al., 1998; Andersson et al., 2007, 2015) based on Simpson et al. (2012). MATCH also includes SOA formed by oxidation of biogenic and anthropogenic volatile organic compounds (ASOA and BSOA). The SOA modelling is based on the volatility basis set (VBS) scheme in the EMEP MSCW model (Bergström et al., 2012, with modifications from Bergström et al., 2014). In the present study, primary organic aerosol emissions were considered non-volatile and VBS schemes were only used for "traditional" ASOA and BSOA; BVOC emissions of isoprene and monoterpenes were calculated in the model, using the methodology of Simpson et al. (2012). A small emission of sesquiterpenes, equal to $5 \%$ of the daytime monoterpene emissions, was added (as in Bergström et al., 2014).

\subsection{Urban-scale air quality modelling and emissions}

In Markakis et al. (2015) we conducted a sensitivity analysis on a decade simulation over IdF to test the response of modelled ozone and $\mathrm{PM}_{2.5}$ concentrations to the refinement of information related to model setup and inputs. On the basis of those findings, in the present study we implement a meshgrid of $4 \mathrm{~km}$ horizontal resolution (consisting of 39 grid cells in the west-east direction and 32 grid cells in the north-south direction), vertically resolved with eight $\sigma-p$ hybrid layers from the surface $(999 \mathrm{hPa})$ up to $5.5 \mathrm{~km}(500 \mathrm{hPa})$. The lowest layer is $25 \mathrm{~m}$ thick. The $1 \mathrm{~km}$ resolution domain, covering Stockholm, consists of $48 \times 48$ grid cells. The vertical resolution follows the layers of the driving regional climate model, distributed between 20 layers with a $60 \mathrm{~m}$ thick surface layer.

Present-time emission estimates for the IdF region are available at a $1 \mathrm{~km}$ resolution grid. Emissions are compiled with a bottom-up approach by the IdF environmental agency (AIRPARIF) combining a plethora of city-specific information (AIRPARIF, 2012). The spatial allocation of emissions is either source specific (e.g. locations of point sources) 
or completed with proxies such as high-resolution population maps and a detailed road network. The inventory has hourly source-specific, temporal resolution. The compilation of present-time emission for the Stockholm region (covering an area of 30 municipalities and 2.2 million inhabitants) is also based on a bottom-up approach - e.g. the estimates of total traffic volumes are primarily based on in situ measurements and variations of vehicle composition and temporal variation of the traffic volumes are described for different road types. Vehicle fleet composition and vehicle exhaust emission factors are based on the Swedish application of the ARTEMIS (Assessment and Reliability of Transport Emission Models and Inventory Systems) model (Sjödin et al., 2006). There are also large non-tailpipe emissions due to road, tyre and break wear. In Stockholm the non-tailpipe emissions dominate and emission factors are estimated based on local measurements (Omstedt et al., 2005; Ketzel et al., 2007). The emission database has hourly source-specific, temporal resolution. More details on the emission data and how they were compiled can be found in Gidhagen et al. (2012).

\subsection{Climate and regional-scale emission projections}

Climate follows the long-term 4.5 scenario of the Representative Concentration Pathways (RCP-4.5) that exhibits a $20 \%$ greenhouse gas emission reduction for Europe, constant population and mid-21st century global radiative forcing at $4 \mathrm{~W} \mathrm{~m}^{-2}$, increasing to $4.5 \mathrm{~W} \mathrm{~m}^{-2}$ by 2065 and stabilizing thereafter (Clarke et al., 2007). Shown in previous work (Markakis et al., 2014), this scenario represents an intermediate alternative between the pessimistic and optimistic RCPs (8.5 and 2.6 respectively) in terms of long-term temperature projection in $\mathrm{IdF}$ with $0.6^{\circ} \mathrm{C}$ increase in the 2050 annual mean temperature compared to $-0.5^{\circ} \mathrm{C}$ for RCP-2.6 and $+1.1^{\circ} \mathrm{C}$ for RCP-8.5.

The European-scale simulations use anthropogenic emissions developed in the framework of the ECLIPSE (Evaluating the Climate and Air Quality Impacts of Short-Lived Pollutants) project (Klimont et al., 2013). It is consistent with the long-term climate projections of the RCPs but also spatial algorithms to improve the representation of short-term continental and national air quality legislations. In this study we used the "Current Legislation Emission" scenario (CLE) for mid-21st century in Europe, which includes both climate and regional air quality policies and assumes full enforcement of all legislated control technologies until 2030 and no climate policy thereafter. CLE projects that $\mathrm{NO}_{x}$, NMVOCs, $\mathrm{PM}_{10}$ and $\mathrm{PM}_{2.5}$ emissions drop in 2050 by $43,35,32$ and $32 \%$ respectively compared to the present day. The MATCH simulations include biomass burning emissions as well taken from the Atmospheric Chemistry and Climate Model Intercomparison Project (ACCMIP) database (Lamarque et al., 2010).

\subsection{Urban-scale emission projections}

The IdF region with the support of the "Direction Regionale et Interdepartementale de l'Environnement et de l'Energie d'Ile de France" (DRIEE-IF), has introduced the "Plan de Protection de l'Atmosphere d'Ile de France" (PPA) enforcing short- and long-term emission cutbacks in order to comply with the national legislation of air pollution concentration reductions. The 2030 emission projection for the IdF region includes gradual renewal of the vehicle fleet according to the latest emission standards (Euro VI), increased use of public transport, replacement of domestic fuel for heating with electricity and gas, new French thermal regulations in buildings, aviation traffic projections and implementation of planned legislation for the industrial sector. The emission projection for the county of Stockholm is founded on vehicle fleet evolution and emission factors for 2030 based on the application of the ARTEMIS model (details found in Gidhagen et al., 2012). Other emissions besides the traffic-related were not changed from the present to the future in Stockholm.

Figure 2 illustrates the annual, sectoral emissions of $\mathrm{NO}_{x}$, NMVOCs, $\mathrm{PM}_{10}$ and $\mathrm{PM}_{2.5}$ in the IdF domain for the present-time and the 2030 scenario. Present-time $\mathrm{NO}_{x}$ emissions mainly stem from the transport sector $(\sim 60 \%$ of annual emissions), largely mitigated by 2030 (emissions decline from 60 to $20 \mathrm{Gg}$ ). The leading emitter of NMVOCs at present-time is the "use of solvents" sector accounting for $49 \%$ of all-sector annual emissions. Interestingly the emissions coming from this sector are hardly mitigated in the future compared to $\mathrm{NO}_{x}$; the corresponding reduction reaches only $11 \%$. The transport, industrial and heating sectors have important $\mathrm{PM}_{10}$ emission shares at present day. The heating and transport sectors are strongly mitigated (reductions reach $\sim 60 \%$ ) while industrial emissions are abated by only $18 \%$ mainly due to the fact that their primary origin is fugitive dust released during production processes whereas the mitigation plan introduces fuel-based reductions. The main contributors of annual fine-particle emissions are the transport and the heating sectors, both strongly mitigated by 2030 (transport sector's emissions drop by $96 \%$ ). Total present-time emissions are reduced by $55 \%$ for $\mathrm{NO}_{x}, 32 \%$ for NMVOCs, $37 \%$ for $\mathrm{PM}_{10}$ and $54 \%$ for $\mathrm{PM}_{2.5}$. For Stockholm about 60 and $80 \%$ of present-time $\mathrm{NO}_{x}$ and $\mathrm{PM}_{10}$ emissions respectively stems from the road transport sector. The decrease in the future (by 16, 18 and $10 \%$ for $\mathrm{NO}_{x}$, NMVOCs and $\mathrm{PM}_{10}$ respectively) in domain-wide emissions is mainly a result of planned renewal of the traffic fleet and stricter emission limits. Finally, as there are no urban-scale emission projections available for the 2030-2050 period we assume that local emissions are unchanged between 2030 and 2050. Nevertheless, this assumption is in line with the European-scale emission scenario (CLE). 

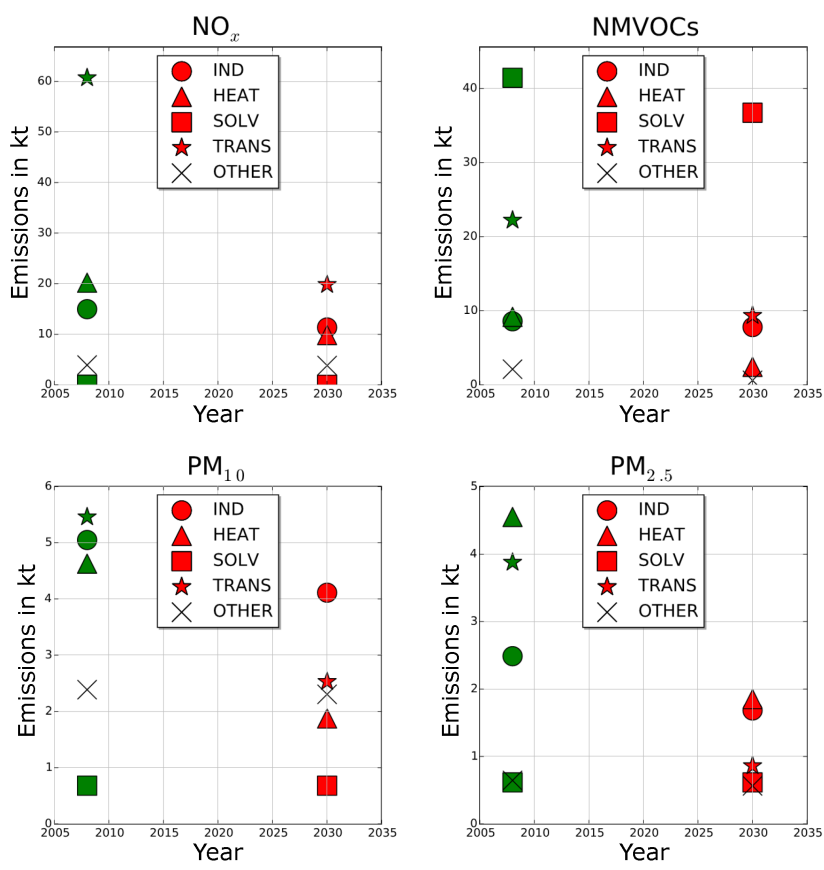

Figure 2. Annual present-time emissions of $\mathrm{NO}_{x}, \mathrm{NMVOCs}, \mathrm{PM}_{10}$ and $\mathrm{PM}_{2.5}$ in IdF and their projections for 2030. IND corresponds to industrial emissions (SNAP1, 3 and 4), HEAT to heating activities (SNAP2), SOLV to solvents use (SNAP6), TRANS to road and nonroad transport (SNAP7 and 8) and OTHER represent the remaining source sectors (SNAP5, 9 and 10).

\section{Model evaluation}

In this section we evaluate the present-day simulations at the study domains. Surface ozone concentrations modelled with CHIMERE and MATCH (averaged over the ozone period which spans from April to August) were compared against all available measurements of the air quality networks included in the high-resolution domains - e.g. 17 urban, five suburban and eight rural sites in IdF and one urban site (Torkel Knutsson) in Stockholm. We also evaluate maximum ozone concentrations calculated from $8 \mathrm{~h}$ running means (MD8hr). Modelled $\mathrm{PM}_{10}$ and $\mathrm{PM}_{2.5}$ ground-level concentrations in summer (JJA), winter (DJF) and on annual basis are also compared to all available measurement sites in the high resolution domains: seven urban stations in IdF and one urban station (Torkel Knutsson) in the Stockholm region. Results are illustrated with scatter plots in Fig. 3. For Stockholm we additionally evaluate the organic carbon (OC) and elemental carbon (EC) as well as sea salt (as sodium) using measurements conducted during the years 2002-2003 and 2013 respectively at the remote site of Aspvreten, located $70 \mathrm{~km}$ southeast of Stockholm. The Aspvreten site is located outside the $1 \mathrm{~km}$ Stockholm domain therefore we use model results from the $12 \mathrm{~km}$ resolution simulation to represent the modelled background. We note that the measurements of particulate matter for the period in question was conducted using the
Tapered-Element Oscillating Microbalance (TEOM) method that has been associated with negative sampling artefacts depending on the season, location and particle size (Allen et al., 1997).

Figure $3 \mathrm{a}$ shows that over the urban stations of IdF, CHIMERE overestimates daily ozone (overall bias $=10 \%$ ) mostly at the urban sites outside the city centre; focusing on downtown monitoring sites the model bias is only $3.7 \%$ (not shown). The simulation successfully reproduces MD8hr. Overestimation of daily ozone is observed at suburban (by $14.6 \%$ ) and rural (by $13.3 \%$ ) stations. Discrepancies in rural ozone may be due to overproduction of isoprene emissions due to a warm modelled bias $\left(+0.3^{\circ}\right.$, not shown) or enhanced advection from the boundaries.

The evaluation of $\mathrm{PM}_{2.5}$ at urban stations (Fig. 3b) shows a negligible mean bias during winter but overestimation by $15.3 \%$ in the summer. Simulations in Markakis et al. (2014), where dust emissions were not included, showed an underestimation of both summer and winter period concentrations suggesting that CHIMERE might overproduce dust particles especially in the drier summer period. On the other hand, a sensitivity analysis conducted with the use of reanalysis meteorology in Markakis et al. (2015) has revealed that the small wintertime $\mathrm{PM}_{2.5}$ bias could be due to model error compensation such as unrealistically high modelled precipitation (not shown) and possible inhibition of vertical mixing or overestimation of wintertime anthropogenic emissions. Wintertime $\mathrm{PM}_{10}$ concentrations appear underestimated (Fig. 3c) provided that the enhanced wet deposition affects the larger particles more. While the exaggeration of summertime dust emissions is also valid for $\mathrm{PM}_{10}$, $\mathrm{PM}_{10}$ concentrations for the same period are generally well represented. It is possible that the stronger modelled winds in the summer compared to observations (not shown) affect the larger particles more, through accelerated dry deposition (Megaritis et al., 2014). The wintertime underestimation of $\mathrm{PM}_{10}$ concentrations is compensated by a positive autumn bias (not shown) leading to unbiased annual average concentrations.

For the Stockholm case we first identified the regional and local contributions to ozone, $\mathrm{PM}_{10}$ and $\mathrm{PM}_{2.5}$ concentrations utilizing measurements from the rural site of Norr Malma. It is sited $80 \mathrm{~km}$ northeast of Stockholm and only slightly affected by urban plumes, therefore we use it as an indicator of the regional influence in the area. The local contribution is defined as the difference between concentrations monitored at the Torkel Knutsson (urban) and Norr Malma (rural) sites. To evaluate the modelled regional contribution, we utilize modelled concentrations at the respective sites. We note that Norr Malma site is located in the $12 \mathrm{~km}$ resolution domain. The Stockholm city exhibits weak titration as the daily mean ozone concentrations measured at the two sites are similar (Table 2). The performance of MATCH is therefore mainly driven by the simulations at the coarser scales which overestimate nighttime ozone (not shown) due to too efficient verti- 

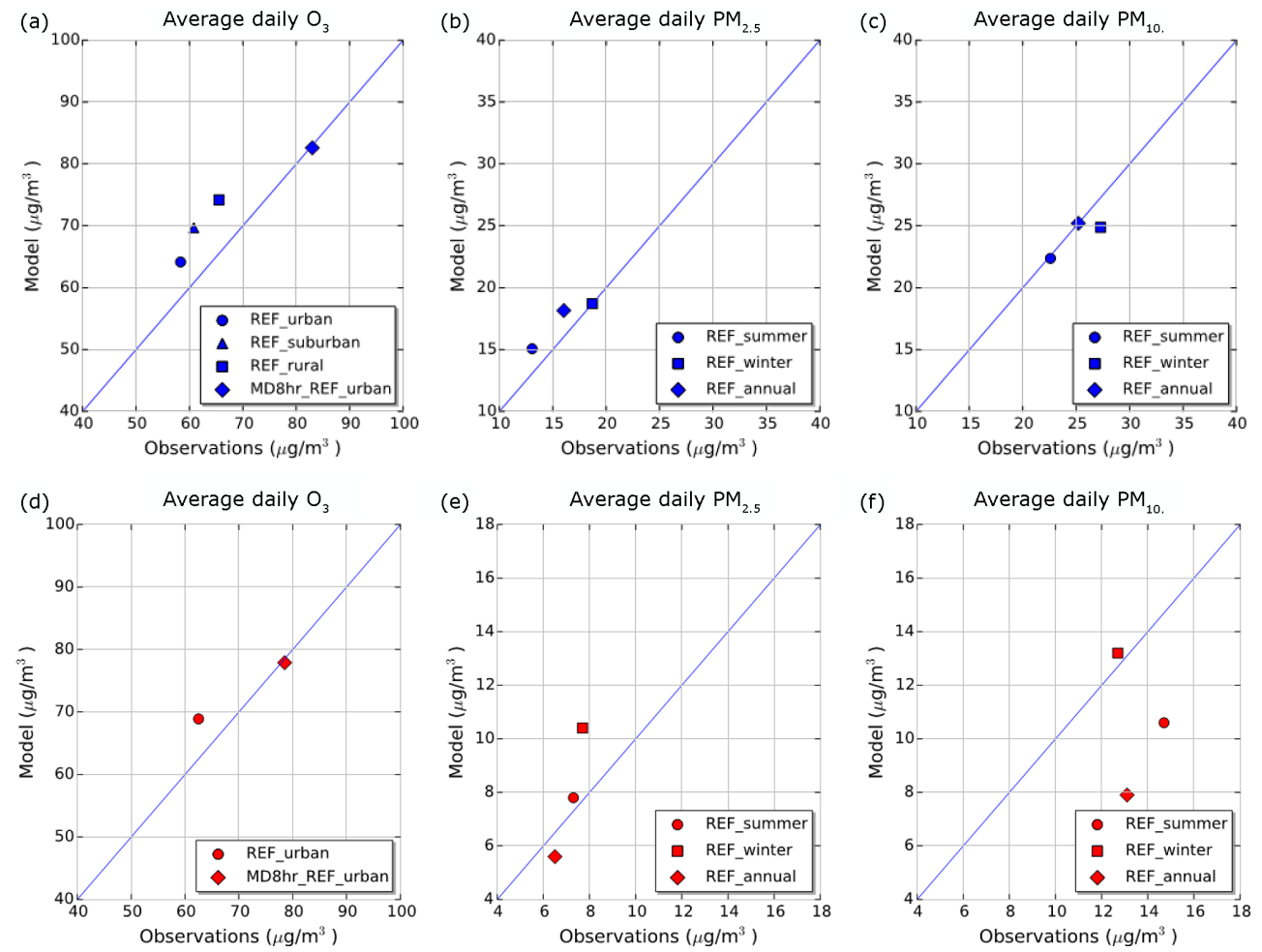

Figure 3. Ozone period (April-August) average ozone concentrations at urban, suburban and rural stations in IdF (a) and one urban station in the Stockholm area (d). The MD8hr values at urban locations are also shown (MD8hr_REF_urban). Average PM 2.5 and PM 10 concentrations in wintertime (DJF), summertime (JJA) and on annual basis over urban stations in IdF are shown in (b, c) (e, f for Stockholm).

Table 2. Quantification of the regional and local contributions to the present-time concentration levels at the city of Stockholm.

\begin{tabular}{lrrr}
\hline & $\begin{array}{r}\text { City } \\
\text { concentration } \\
\text { levels } \\
\left(\mu \mathrm{g} \mathrm{m}^{-3}\right)^{\mathrm{a}}\end{array}$ & $\begin{array}{r}\text { Local } \\
\text { contribution }^{\mathrm{b}}\end{array}$ & $\begin{array}{r}\text { Regional } \\
\text { contribution }^{\mathrm{c}}\end{array}$ \\
\hline Ozone daily mean & 62.5 & -0.8 & 63.3 \\
Ozone MD8hr & 78.5 & -3.3 & 81.8 \\
$\mathrm{PM}_{10}$ annual mean & 14.7 & 5.7 & 9.0 \\
$\mathrm{PM}_{10}$ JJA mean & 13.1 & 3.5 & 9.6 \\
$\mathrm{PM}_{10}$ DJF mean & 12.7 & 4.4 & 8.3 \\
$\mathrm{PM}_{2.5}$ annual mean & 7.3 & 1.9 & 5.4 \\
$\mathrm{PM}_{2.5} \mathrm{JJA}$ mean & 6.5 & 1.5 & 5.0 \\
$\mathrm{PM}_{2.5}$ DJF mean & 7.7 & 2.0 & 5.7 \\
\hline a Based on the only available urban background station in the domain (Torkel Knutsson). \\
b Calculated from the concentration difference between the Torkel Knutsson and the Norr \\
Malma sites. ${ }^{\mathrm{c}}$ Based on measured concentrations at the Norr Malma site.
\end{tabular}

cal mixing during the night; this causes the MATCH model to overestimate the regional contribution in Stockholm by $17 \%$ (not shown), which also explains the major part of the positive bias at the $1 \mathrm{~km}$ resolution simulation by $10 \%$ (Fig. 3d). In contrast, the regional contribution in modelled MD8hr is well represented (bias $<1 \%$ ) leading to unbiased MD8hr in the high-resolution modelling.
Annual mean $\mathrm{PM}_{2.5}$ concentrations are accurately reproduced (Fig. 3e) by the MATCH model over the city but summertime levels are overestimated by $14 \%$ and wintertime by $40 \%$. This is due to a large overproduction in total sea salt in the Stockholm domain, during the whole year $\left(+2.1 \mu \mathrm{g} \mathrm{m}^{-3}\right)$, but mostly during winter $\left(+3 \mu \mathrm{g} \mathrm{m}^{-3}\right)$. Despite this, an underestimation of $\mathrm{PM}_{10}$ concentrations by $26 \%$ is observed over the whole year (Fig. $3 \mathrm{f}$ ). This is due to a large summertime underprediction of $\mathrm{PM}_{10}(40 \%)$, partly explained by the model's lack of aerosols of biogenic origin, which are mainly assigned to the coarse mode of the size distribution. Spores and other primary organic material have an important contribution to the speciation of the organic aerosol in northern Europe (20 to $32 \%$ of the total carbon during summer; Yttri et al., 2011). Another possible reason is the underestimation of OC (by $1.5 \mu \mathrm{g} \mathrm{m}^{-3}$ ) and EC (by $0.1 \mu \mathrm{g} \mathrm{m}^{-3}$ ), which is probably due to the bias inherited by the regional-scale simulations since less than 38 and $26 \%$ of city's $\mathrm{PM}_{10}$ and $\mathrm{PM}_{2.5}$ concentrations respectively stem from local sources (Table 2). The regional contribution to $\mathrm{PM}_{10}$ concentrations based on monitor data is about $60 \%$ but due to the aforementioned reasons $17 \%$ lower based on the MATCH simulation (annual mean) mainly stemming from the summer period $(-43 \%)$. 
Table 3. Future changes in key meteorological variables in the study regions under the RCP-4.5 climate scenario. Seasonal averages include both daytime and nighttime values.

\begin{tabular}{|c|c|c|c|c|}
\hline \multirow{2}{*}{$\begin{array}{l}\text { IdF } \\
\text { Variable }\end{array}$} & \multicolumn{2}{|c|}{ Summer (JJA) } & \multicolumn{2}{|c|}{ Winter (DJF) } \\
\hline & REF & 2050 & REF & 2050 \\
\hline $2 \mathrm{~m}$ temperature $\left({ }^{\circ} \mathrm{C}\right)$ & 18.8 & +0.2 & 4.2 & +0.4 \\
\hline Specific humidity $\left(\mathrm{g} \mathrm{kg}^{-1}\right)$ & 7.9 & +0.3 & 3.4 & +0.2 \\
\hline Precipitation $\left(\mathrm{kg} \mathrm{m}^{-2}\right)$ & 118 & +7.1 & 130 & +4.7 \\
\hline Radiation $\left(\mathrm{W} \mathrm{m}^{-2}\right)$ & 262 & -6.5 & 50 & -1.9 \\
\hline $10 \mathrm{~m}$ wind speed $\left(\mathrm{m} \mathrm{s}^{-1}\right)$ & 4.0 & +0.2 & 6.8 & -0.2 \\
\hline Boundary layer height (m) & 643 & +22 & 727 & -41 \\
\hline Stockholm domain & \multicolumn{2}{|c|}{ Summer (JJA) } & \multicolumn{2}{|c|}{ Winter (DJF) } \\
\hline Variable & REF & 2050 & REF & 2050 \\
\hline $2 \mathrm{~m}$ temperature $\left({ }^{\circ} \mathrm{C}\right)$ & 12.9 & +1.3 & -1.2 & +1.4 \\
\hline Specific humidity $\left(\mathrm{g} \mathrm{kg}^{-1}\right)$ & 7.7 & +0.6 & 3.1 & +0.3 \\
\hline Precipitation $\left(\mathrm{kg} \mathrm{m}^{-2}\right)$ & 223 & -14 & 159 & +2.7 \\
\hline Radiation $\left(\mathrm{W} \mathrm{m}^{-2}\right)$ & 232 & -0.4 & 28.2 & -0.7 \\
\hline $10 \mathrm{~m}$ wind speed $\left(\mathrm{m} \mathrm{s}^{-1}\right)$ & 3.2 & -0.1 & 4.3 & -0.1 \\
\hline Boundary layer height (m) & 673 & +6 & 574 & -11 \\
\hline
\end{tabular}

\section{Climate projections for 2050}

In Table 3 we show the projected domain-wide values of key meteorological variables. A warmer climate is expected in both regions. Surface temperature in $\mathrm{IdF}$ increases by $0.2^{\circ} \mathrm{C}$ in summer and $0.4^{\circ} \mathrm{C}$ in winter while in the Stockholm domain this trend is stronger reaching $+1.3^{\circ} \mathrm{C}$ in summer and $+1.4^{\circ} \mathrm{C}$ in winter. During the summer months, when ozone formation mainly occurs, no significant change in solar radiation is observed. Ground-level wintertime specific humidity rises by $\sim 6 \%$ in IdF and by +7 and $+9.7 \%$ in summer and winter respectively over Stockholm. The effect of humidity on ozone levels is ambiguous (see Jacob and Winner, 2009, for a thorough discussion); elevated levels are linked with lower levels of background ozone (Johnson et al., 1999) even though some have found a weak effect in more polluted atmospheres (Aw and Kleeman, 2003). Changes in the planetary boundary layer height (PBL) affect pollutants dispersion. In IdF we observe an increase by $3.4 \%$ in PBL during the summer and decrease by $5.6 \%$ during winter. In the Stockholm domain projected changes in the PBL are less than $2 \%$.

The precipitation rate, a regulating factor of PM concentrations, increase by 6.5 and $3.6 \%$ during summer and winter respectively in IdF whereas summertime precipitation in the Stockholm domain decreases by $6.3 \%$ and wintertime levels increase by only $1.7 \%$. Nitrate concentrations are expected to increase with humidity due to shift of the ammonia-nitric acid equilibrium to the aerosol phase (Seinfeld and Pandis, 2006) but to decrease due to the higher temperatures. On the other hand, sulfates increase with the warmer climate while there is evidence that elevated humidity may also lead to decrease in particle concentration by increasing the water content of particles and accelerating dry deposition rates (Megaritis et al., 2014). A warmer climate may also affect secondary organic production since semi-volatile pollutants are more prone to the gas phase under warm temperatures. Furthermore, climate-change-induced changes to the oxidizing capacity may cause changes to the volatility of organic gases.

\section{Air quality modelling analysis}

\subsection{Present time}

Maps of present-time daily mean ozone concentrations (in the ozone period) and annual mean $\mathrm{PM}_{10}$ and $\mathrm{PM}_{2.5}$ concentrations are illustrated in the left columns of Figs. 4 and 5 for IdF and Stockholm domain respectively. Concentrations that are spatially averaged over the cities of Paris and Stockholm (see Fig. 1) and domain-averaged concentrations that are representative of rural areas, are discussed separately. Consequently, lower ozone concentrations are found over the city centres due to titration while higher levels are modelled at the surrounding areas due to photochemical formation (IdF) or long-range transport (Stockholm). The urban increment of daily mean ozone, defined here as the difference between the urban and the domain-averaged concentration, is $-13 \mu \mathrm{g} \mathrm{m}^{-3}$ in IdF and only $-1 \mu \mathrm{g} \mathrm{m}^{-3}$ in the Stockholm domain. Ozone formation in IdF is VOC-limited and therefore the titration rate over Paris is high (Markakis et al., 2014). In contrast, ozone levels over the city of Stockholm are mainly due to transport from the boundaries and much less affected by local $\mathrm{NO}_{x}$ emission and titration (see also discussion in the previous section). Annual $\mathrm{PM}_{2.5}$ and $\mathrm{PM}_{10}$ concentrations (Fig. 4e, i) are high over areas of intense anthropogenic activity such as the Charles-de-Gaulle international airport (northeast in the IdF domain), the city centre and the suburbs of Paris due to road transport and wintertime heating emissions while local dust contributes with $\mathrm{PM}_{10}$ emissions to the south. The spatial pattern of $\mathrm{PM}_{2.5}$ and $\mathrm{PM}_{10}$ concentrations in the Stockholm domain mainly reflects major roads, i.e. traffic emissions (Fig. 4e, i).

\subsection{Future air quality at 2050 due to climate change}

Figures 4 and 5 show the future changes (compared to present-time) in daily mean ozone concentrations (over the ozone period) and annual mean $\mathrm{PM}_{10}$ and $\mathrm{PM}_{2.5}$ concentrations, due (i) only to climate change; (ii) only to emission reductions and (iii) to the combined effect of climate and emissions for IdF and Stockholm regions respectively. The spatial distribution of the ozone concentration difference between present and future reveal that despite the overall increase of mean surface temperature there is a domainwide climate benefit for both domains. In Paris reductions in the daily and MD8hr ozone concentrations reach $\sim 5 \%$ (Ta- 
(a)

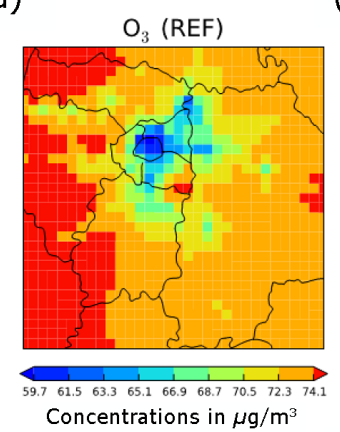

(e)

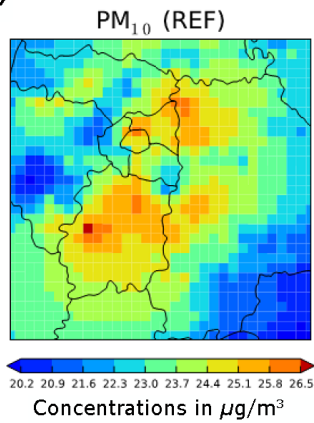

(i)

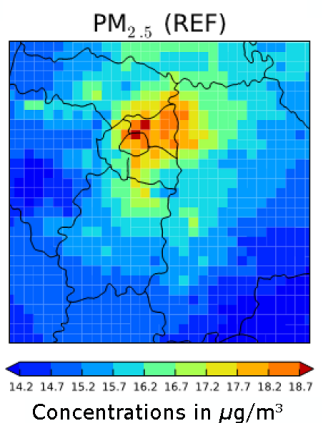

(b)

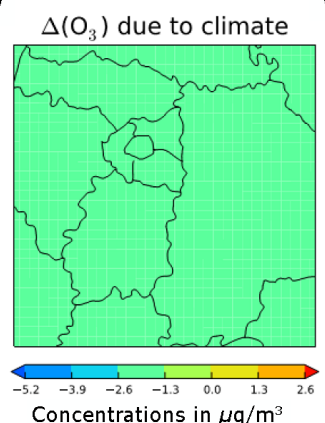

(f)

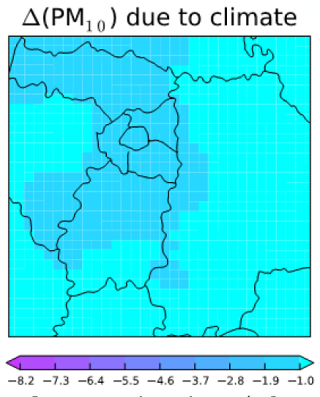

Concentrations in $\mu \mathrm{g} / \mathrm{m}^{3}$

(j)

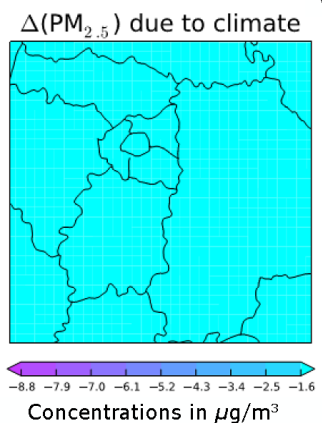

(c)

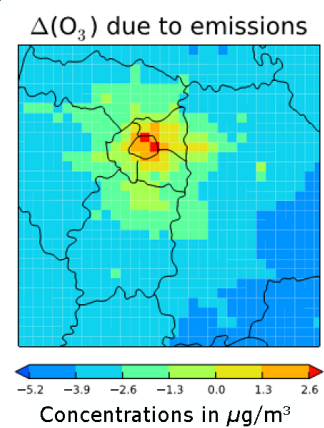

(g)

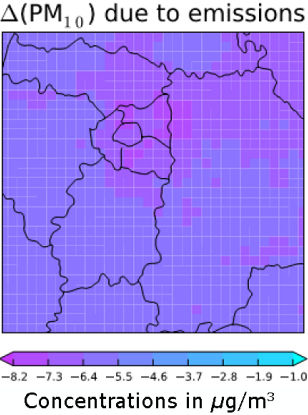

(k)
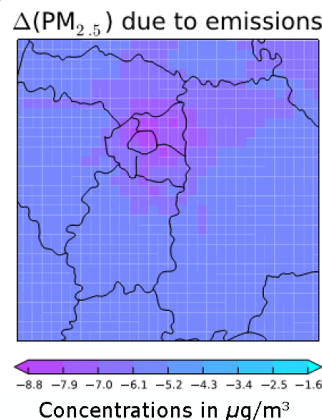

(d)

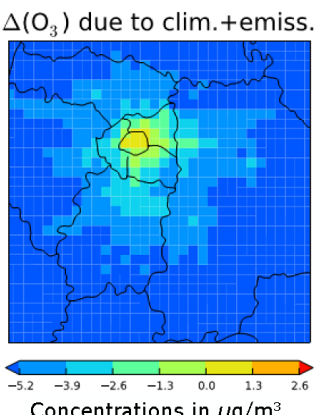

(h)

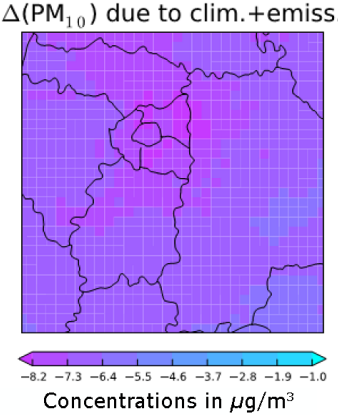

(I)

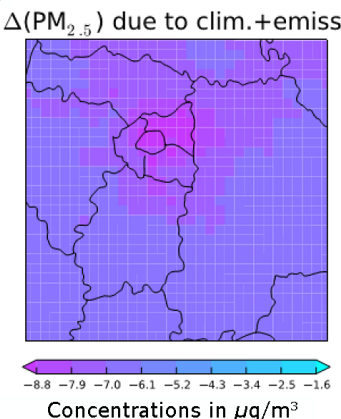

Figure 4. April-August mean ozone, annual mean $\mathrm{PM}_{10}$ and annual mean $\mathrm{PM}_{2.5}$ concentration maps $\left(\mu \mathrm{g} \mathrm{m}{ }^{-3}\right)$ for IdF, expressed as absolute values at present-time (a, e, i) and as deltas between present-time and 2050 due to climate change $(\mathbf{b}, \mathbf{f}, \mathbf{j})$, emissions changes $(\mathbf{c}, \mathbf{g}, \mathbf{k})$ and the cumulative effect $(\mathbf{d}, \mathbf{h}, \mathbf{l})$.

ble 4). To some extent this is explained by the locale climate change; decrease in surface ozone despite the warmer climate has been also observed by other researchers (Coleman et al., 2014; Lauwaet et al., 2014) and linked with enhanced ozone destruction through the $\mathrm{O}_{3}+\mathrm{OH} \rightarrow \mathrm{HO}_{2}+\mathrm{O}_{2}$ reaction due to increase in $\mathrm{OH}$ radicals triggered by higher surface water vapour $\left(\mathrm{O}\left({ }^{1} \mathrm{D}\right)+\mathrm{H}_{2} \mathrm{O} \rightarrow 2 \mathrm{OH}\right)$. For Paris this is consistent with the fact that $\mathrm{NO}_{x}$ concentrations are not much affected in the future $\left(|\Delta c|=1.2 \mu \mathrm{g} \mathrm{m}^{-3}\right)$ and therefore the decrease in ozone cannot be attributed to enhanced titration. The increase of the summertime period PBL height could also be responsible for the declining ozone trends through less dispersed primary $\mathrm{NO}_{x}$ emissions. Most probably changes in regional climate are responsible for the observed trend - i.e. a weakened outflow from North America which is known to affect Europe through the north and western boundaries (Au- vray and Bey, 2005; Lacressonniere et al., 2014). This is consistent with the fact that Paris and the IdF average responses are equivalent (Table 4), also evident in the Stockholm case which is known to have significant regional influence. Overall ozone concentration response in the Stockholm domain is negligible ( $\sim 2 \%$ for daily mean and MD8hr ozone) driven by the respective response at the regional level (Watson et al., 2015).

Changes in future concentrations of particles in IdF are up to 5 and $10 \%$ for $\mathrm{PM}_{10}$ and $\mathrm{PM}_{2.5}$ respectively, depending on season and area of focus (Paris or IdF average, Table 4). There is a weak climate benefit for annual concentrations of PM over Paris and the domain, mainly due to enhanced summertime precipitation. A small increase in PM concentrations over Paris is observed in wintertime as a result of a shallower boundary layer and higher temperatures 
(a)

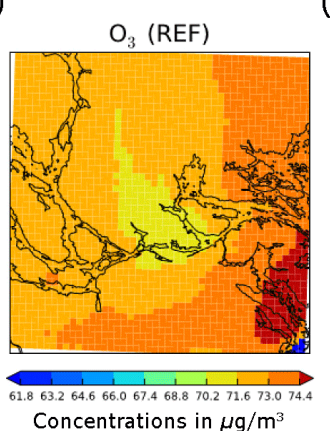

(e)

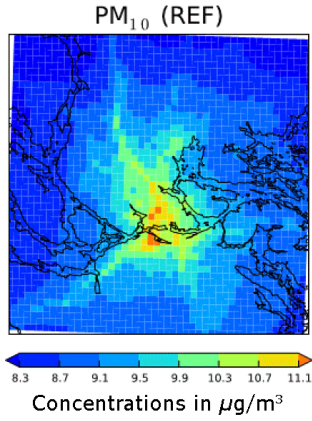

(i)

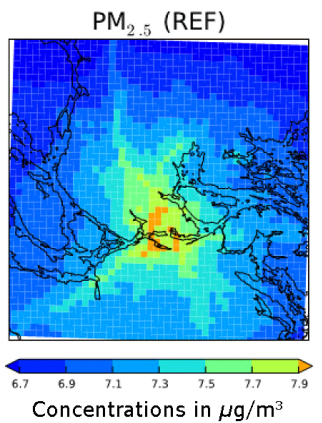

(b)

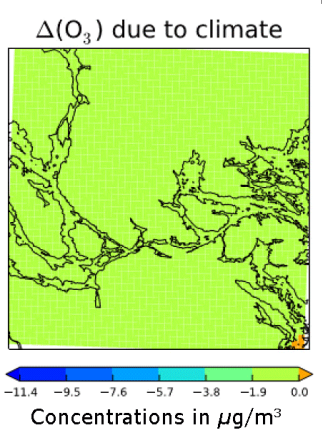

(f)

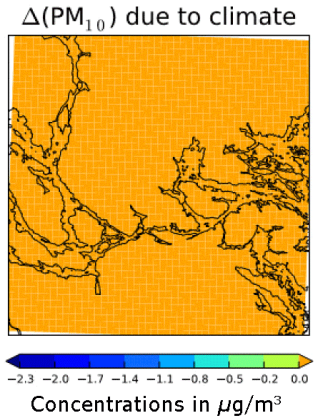

(j)

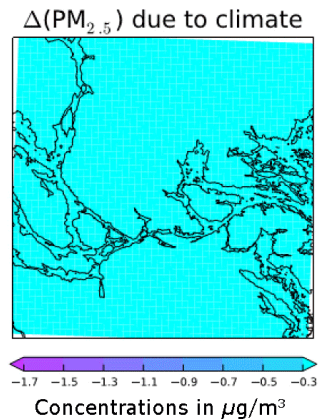

(c)

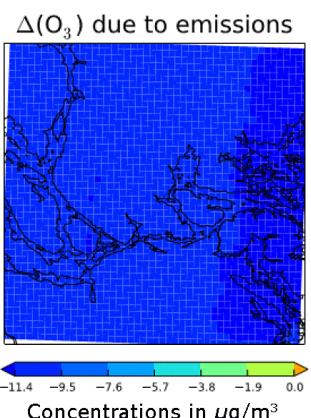

(g)

$\Delta\left(P M_{10}\right)$ due to emissions

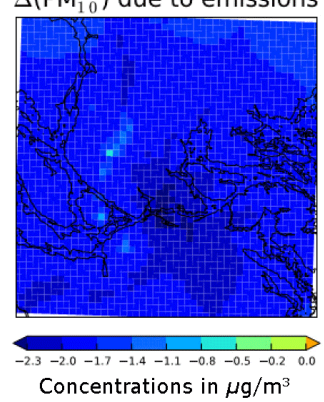

(k)

$\Delta\left(\mathrm{PM}_{25}\right)$ due to emissions

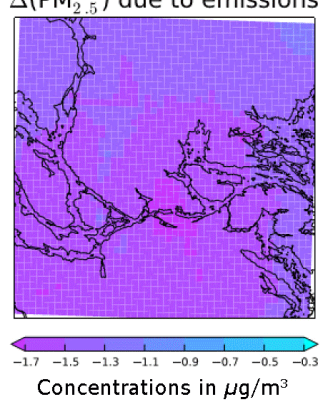

(d)

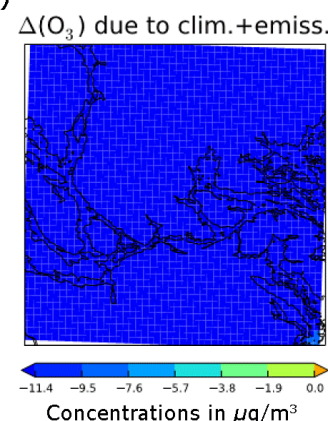

(h)

$\Delta\left(\mathrm{PM}_{10}\right)$ due to clim. + emiss

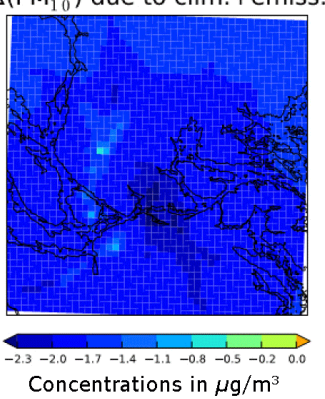

(I)

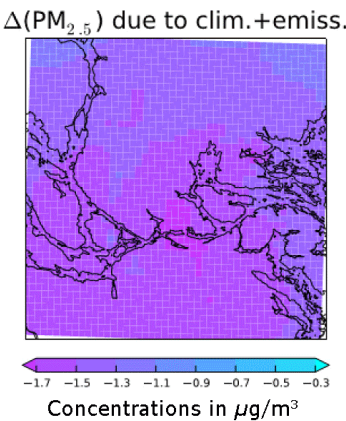

Figure 5. Similar to Fig. 4 for Stockholm.

that positively affect sulfates. PM annual concentrations over the Stockholm domain remain practically unchanged; a weak decrease of $3 \%$ is only estimated during winter, and similarly to ozone it is linked to regional-scale changes.

\subsection{Local air quality at 2050 due to emission reductions}

The spatial distribution of changes in mean daily ozone concentrations due to emission mitigation in the IdF region reveals two opposing trends (Fig. 4c); in Paris there is an overall increase of daily ozone by $4.8 \mathrm{\mu g} \mathrm{m}^{-3}$ (Table 4) despite the enforced $\mathrm{NO}_{x}$ emission mitigation. Under the VOClimited photochemical regime characterizing the city, $\mathrm{NO}_{x}$ abatement inhibits the ozone titration process resulting in higher ozone levels. The magnitude of the ozone increase due to emission mitigation outbalances the predicted climate benefit and the combined effect leads to an overall penalty of $+1.5 \mu \mathrm{g} \mathrm{m}^{-3}$ over Paris. In contrast, the domain-wide ozone concentrations decrease by $6.5 \mu \mathrm{g} \mathrm{m}^{-3}$, since ozone over the rural areas is less affected by titration (Markakis et al., 2014). It is worth noting that the absolute change in the MD8hr concentration over Paris due to climate change is 2 times higher than due to emission mitigation (Table 4). Therefore, while local emission mitigation has a stronger impact on background ozone levels, climate change affects more the ozone peaks (found at around 15:00 LT in Paris). This may be particularly interesting from a health impact assessment standpoint where the MD8hr indicator is typically implemented (Likhvar et al., 2015).

Emission reduction policies appear to be more efficient for ozone abatement over the Stockholm region, with reductions reaching $\sim 11$ and $\sim 13 \mu \mathrm{g} \mathrm{m}^{-3}$ for the mean and MD8hr respectively, indistinguishably for the city and the domainaveraged concentrations (Table 4). Based on the sensitivity simulations we find that the observed ozone decrease is entirely attributed to emission mitigation at the regional rather 
Table 4. Changes in pollutant concentrations (in $\mu \mathrm{g} \mathrm{m}^{-3}$ ) between present (REF) and 2050 for the IdF and Stockholm regions due to climate change, emission reduction policies and their combined effect. Results are presented separately for the urban centres (Paris and Stockholm cities) and the domain averages. Ozone is averaged over the April-August period.

\begin{tabular}{|c|c|c|c|c|c|c|c|c|}
\hline \multirow[b]{2}{*}{ Paris } & \multicolumn{2}{|c|}{ Ozone } & \multicolumn{3}{|c|}{$\mathrm{PM}_{10}$} & \multicolumn{3}{|c|}{$\mathrm{PM}_{2.5}$} \\
\hline & mean & MD8hr & JJA & DJF & annual & JJA & DJF & annual \\
\hline REF & 60 & 79 & 22 & 25 & 25 & 15 & 19 & 18 \\
\hline clim. & -3.3 & -4.1 & -1.1 & +0.6 & -1.1 & -1.5 & +0.1 & -1.2 \\
\hline emiss. & +4.8 & +2.2 & -4.7 & -8.1 & -7.2 & -5.8 & -8.7 & -8.1 \\
\hline clim. + emiss. & +1.5 & -1.9 & -5.8 & -7.5 & -8.3 & -7.3 & -8.6 & -9.3 \\
\hline IdF Domain & mean & MD8hr & JJA & DJF & annual & JJA & DJF & annual \\
\hline REF & 73 & 92 & 22 & 21 & 23 & 14 & 14 & 15 \\
\hline clim. & -3.7 & -4.2 & +0.2 & -0.2 & -0.7 & -1.0 & 0.0 & -1.0 \\
\hline emiss. & -6.5 & -11.4 & -4.0 & -6.6 & -6.3 & -4.1 & -6.0 & -5.9 \\
\hline clim. + emiss. & -10.2 & -15.6 & -3.8 & -6.8 & -7.0 & -5.1 & -6.0 & -6.9 \\
\hline Stockholm & mean & MD8hr & JJA & DJF & annual & JJA & DJF & annual \\
\hline REF & 72 & 81 & 7 & 12 & 10 & 5.3 & 10 & 7.4 \\
\hline clim. & -1.3 & -1.7 & +0.1 & -0.4 & 0.0 & 0.0 & -0.3 & 0.0 \\
\hline emiss. & -11 & -12.7 & -1.3 & -2.2 & -2.0 & -1.0 & -1.8 & -1.6 \\
\hline clim. + emiss. & -12.3 & -14.4 & -1.2 & -2.6 & -2.0 & -1.0 & -2.1 & -1.6 \\
\hline Stockholm domain & mean & MD8hr & JJA & DJF & annual & JJA & DJF & annual \\
\hline REF & 73 & 81.5 & 6.6 & 11 & 9 & 5 & 9.5 & 7 \\
\hline clim. & -1.3 & -1.1 & +0.1 & -0.3 & +0.1 & 0.0 & -0.3 & 0.0 \\
\hline emiss. & -11.4 & -13.1 & -1.3 & -2.3 & -1.9 & -1.0 & -1.9 & -1.6 \\
\hline clim. + emiss. & -12.7 & -14.2 & -1.2 & -2.6 & -1.8 & -1.0 & -2.2 & -1.6 \\
\hline
\end{tabular}

Table 5. Contribution of the emission reduction policies implemented at the local and regional scale to the future concentration changes of ozone, $\mathrm{PM}_{10}$ and $\mathrm{PM}_{2.5}$ in the Stockholm domain.

\begin{tabular}{lrrrrrrrrrr}
\hline & \multicolumn{2}{c}{ Ozone } & & \multicolumn{3}{c}{$\mathrm{PM}_{10}$} & & \multicolumn{3}{c}{$\mathrm{PM}_{2.5}$} \\
\cline { 2 - 3 } \cline { 9 - 11 } Stockholm domain & mean & MD8hr & & JJA & DJF & annual & & JJA & DJF & annual \\
\hline REF & 73 & 81.5 & & 6.6 & 11 & 9 & & 5 & 9.5 & 7 \\
local & +0.1 & +0.1 & & -0.1 & -0.1 & -0.1 & & 0.0 & 0.0 & 0.0 \\
regional & -11.5 & -13.2 & & -1.2 & -2.4 & -1.8 & & -1.0 & -1.9 & -1.6 \\
local + regional & -11.4 & -13.1 & & -1.3 & -2.3 & -1.9 & & -1.0 & -1.9 & -1.6 \\
\hline
\end{tabular}

than the urban scale (Table 5). We should note, however, that the role of local emission reductions is probably underestimated in Stockholm due to lack of non-traffic emission abatement, although traffic is the main contributor to the Stockholm $\mathrm{NO}_{x}$ emissions, contributing $\sim 50 \%$ to the total even after the future reductions.

Particle concentrations are very sensitive to their primary emission changes (Markakis et al., 2015). Therefore, it is not surprising that PM concentration reductions are mainly due to emission mitigation in both domains (Table 4). The domain-wide annual mean in IdF declines by 7.2 and $8.1 \mathrm{\mu g} \mathrm{m}^{-3}$ and in the Stockholm domain by 1.9 and $1.6 \mu \mathrm{g} \mathrm{m}^{-3}$ for $\mathrm{PM}_{10}$ and $\mathrm{PM}_{2.5}$ respectively. In IdF the decrease is higher over areas and seasons with high primary PM - e.g. Paris compared to the rural areas of IdF (Fig. 4g, k), as well as in wintertime compared to summertime $\left(-8.7 \mu \mathrm{g} \mathrm{m}^{-3}\right.$ vs. $-5.8 \mu \mathrm{g} \mathrm{m}^{-3}$ respectively for annual mean $\mathrm{PM}_{2.5}$, due to significant abatement in the heating sector. In contrast, in the Stockholm domain the seasonal and spatial distribution of changes are much less prominent due to the prevailing regional influence (Table 5).

We have assumed unchanged local-scale emissions for the 2030-2050 period. Nevertheless, the projected concentration change in the Stockholm region is mostly affected 
by regional emission mitigation that according to the CLE emission scenario is weak. Therefore, further mitigation of urban-scale emissions would not strongly affect the future concentration change in the Stockholm domain. In contrast, additional emission mitigation in the IdF scale would result in further improvement of domain-wide ozone and $\mathrm{PM}_{2.5}$ related air quality at the mid-21st century horizon. However, due to highly non-linear ozone chemistry over Paris, it is difficult to make firm assumptions on the nature of ozone projected changes, under additional mitigation of ozone precursor emissions in the 2030-2050 period.

\subsection{Future evolution of ozone chemical regimes under local- and regional-scale chemistry-transport modelling in Paris}

In this section we study the long-term evolution of ozone chemical regimes in the city of Paris. This analysis is not performed for Stockholm where ozone concentrations are controlled by long-range transport and less by the local chemistry which determines the regime. For each simulated day in the ozone period, in both present and future decades, we determine daily average concentrations of $\mathrm{NO}_{y}$ and the ratios of $\mathrm{O}_{3} / \mathrm{NO}_{y}, \mathrm{H}_{2} \mathrm{O}_{2} / \mathrm{NO}_{y}$ and $\mathrm{H}_{2} \mathrm{O}_{2} / \mathrm{NO}_{z}$. The threshold values proposed in order to discriminate between the two chemical regimes (i.e. $\mathrm{NO}_{x}$ or VOC-limited) are $7.6 \mathrm{ppb}$ for $\mathrm{NO}_{y}$ (Beekman and Vautard, 2010), 5.5 for $\mathrm{O}_{3} / \mathrm{NO}_{y}$ (Sillman et al., 2003), 0.12 for $\mathrm{H}_{2} \mathrm{O}_{2} / \mathrm{NO}_{y}$ (Sillman and $\mathrm{He}$, 2002) and between 0.21 and 0.41 for $\mathrm{H}_{2} \mathrm{O}_{2} / \mathrm{NO}_{z}$ (Beekman and Vautard, 2010). The aforementioned analysis is applied on both regional (coarse-res) and urban-scale (highres) simulations for present and future decades. Three indicators agree on a VOC-limited characterization of presenttime ozone production at the urban-scale simulation in agreement to the findings of Markakis et al. (2014) while only one indicator classifies the regional-scale ozone simulation as VOC-limited (Fig. 6). Despite a similar trend towards a more $\mathrm{NO}_{x}$-limited photochemistry in 2050 at both high and coarse simulations, still three out of four indicators characterize the high-resolution simulation as VOC-limited at 2050 whereas the coarse resolution is positively $\mathrm{NO}_{x}$-limited according to all four indicators.

\subsection{Policy implications based on comparison of air quality projections from high- and coarse-resolution modelling}

Air quality projections for 2050 indicate that ozone levels in Paris will increase by 8 and $3 \%$ for daily mean and MD8hr respectively as a response to the enforced emission mitigation plan. In contrast, the coarse-resolution simulation yields 7 and $15 \%$ decrease in these metrics (Table 6). A similar inconsistency was found in Markakis et al. (2014), where the Global Energy Assessment (GEA) emission projection (GEA, 2012) was used instead of the ECLIPSE inventory.
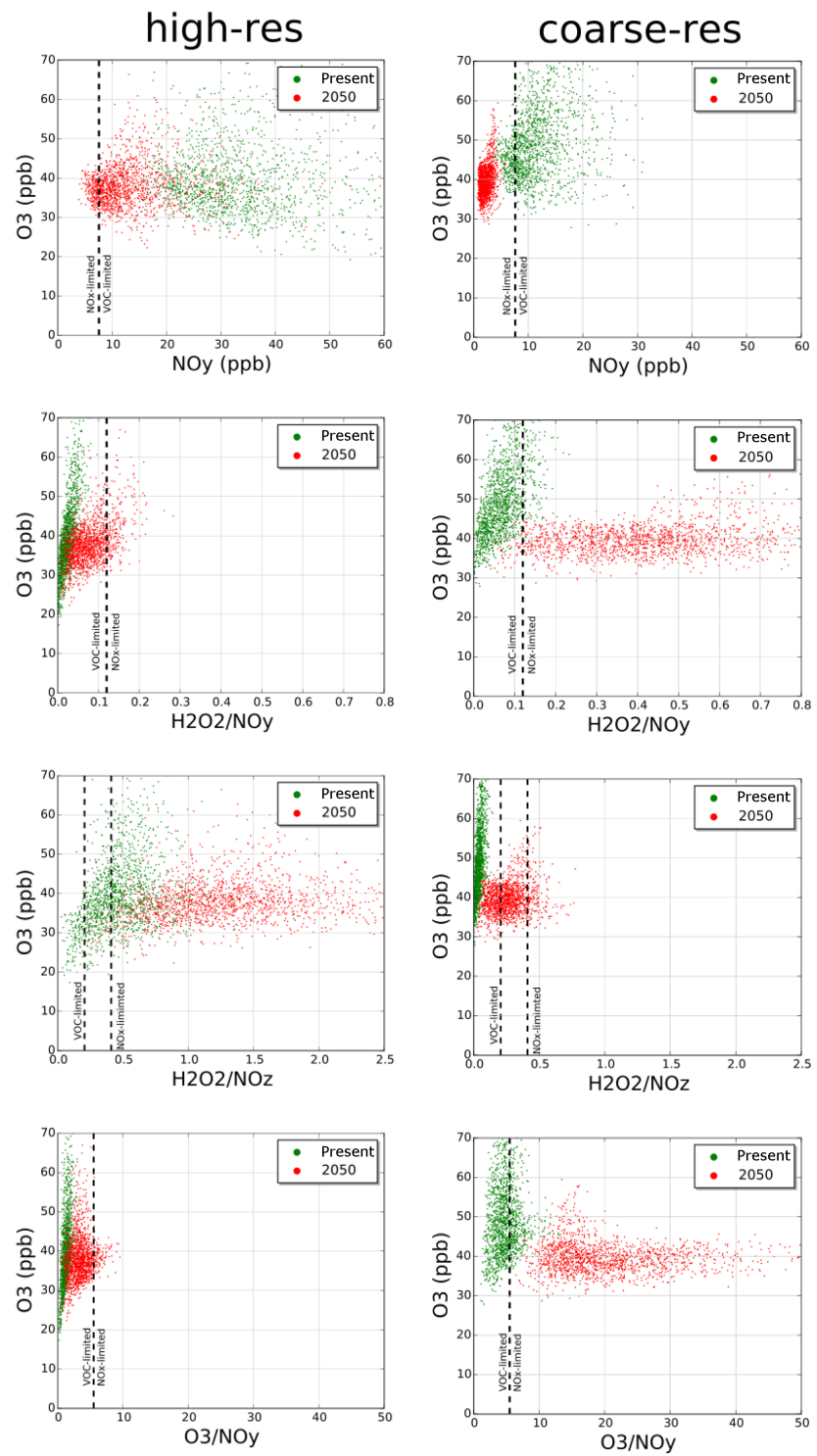

Figure 6. Scatter plots of daily average ozone concentrations ( $y$ axis) against chemical regime indicators ( $x$ axis) for the present and future runs in Paris. Results are presented for the highresolution (left panels) and the coarse-resolution (right panels) applications. Dots correspond to daily average concentrations for each day of the ozone period. For each indicator the limit value that separates the regimes is also depicted with a dashed line.

ECLIPSE stands as another state-of-the-art emission inventory, explicitly designed for air quality projections in order to cope with the drawbacks (Butler et al., 2012) of their global counterparts such as the RCPs which were intended for use in global-scale climate studies. As discussed in the previous section, ozone production in the coarse-resolution simulation by 2050 will shift from a VOC- to a $\mathrm{NO}_{x}$-limited photochemical regime and therefore be more responsive to reductions of $\mathrm{NO}_{x}$ emissions compared to the urban-scale simulation where the transition to $\mathrm{NO}_{x}$-limited conditions is smoother. 
Table 6. Future concentration response relative to present (in \%) under the high- and coarse-resolution applications over the city of Paris and the IdF domain.

\begin{tabular}{|c|c|c|c|c|c|c|c|c|}
\hline & \multicolumn{2}{|c|}{ Ozone } & \multicolumn{3}{|c|}{$\mathrm{PM}_{10}$} & \multicolumn{3}{|c|}{$\mathrm{PM}_{2.5}$} \\
\hline & mean & MD8hr & JJA & DJF & annual & JJA & DJF & annual \\
\hline Paris high-res & +8 & +3 & -21 & -32 & -32 & -38 & -46 & -44 \\
\hline Paris coarse-res & -7 & -15 & -34 & -47 & -42 & -43 & -55 & -52 \\
\hline IdF high-res & -9 & -12 & -18 & -32 & -27 & -29 & -42 & -39 \\
\hline IdF coarse-res & -9 & -16 & -29 & -41 & -37 & -39 & -52 & -49 \\
\hline
\end{tabular}

PM concentrations over Paris under the high-resolution modelling are expected to decrease by 21 to $46 \%$ depending on the season and particle cut-off diameter while the coarseresolution simulation is about $10 \%$ more optimistic with reductions ranging from 34 to $55 \%$. Both the evolution of chemical regimes and of PM concentrations are attached to the underlying emission projections. Under the coarse-scale storyline (CLE), annual emissions of $\mathrm{NO}_{x}$ over Paris drop by almost an order of magnitude while the local inventory yields a reduction of $66 \%$. Annual $\mathrm{PM}_{10}$ and $\mathrm{PM}_{2.5}$ emissions in Paris drop by $76 \%$ according to CLE while only by 10 and $38 \%$ respectively according to the local projection.

Given that the coarse inventory implements assessment at the large scale, its stronger mitigation over the city of Paris compared to the AIRPARIF projection is due to omission of local policy. The downscaling of coarse inventories on regional-scale CTM grids passes through spatial proxies (such as land-use) to distribute emissions and the related bias induced to the air quality simulation over finer areas increases the overall bias of the application as well. The difference in the response of the regional- and urban-scale simulations is due, to a large extent, to the spatial allocation algorithm (inherited by the RCPs) used in the compilation of both GEA and ECLIPSE databases (Riahi et al., 2011), which forces stronger (and possibly unrealistic) mitigation over the urban areas. Additionally, regional inventories assimilate regional/national legislation. In Europe the UNECE/LRTAP convention under the revised Gothenburg protocol (http://www.unece.org/fr/env/lrtap/status/lrtap_s.html) bounds the European member states (EU28) to achieve at a 2020 horizon relative to 2005 an overall reduction by $42 \%$ in $\mathrm{NO}_{x}$ emissions and $28 \%$ in NMVOCs emissions. Such reductions enhance the shift towards $\mathrm{NO}_{x}$-limited ozone production. This suggests that coarse-resolution ozone projections may be too optimistic over VOC-limited areas, mainly found in northwestern Europe (Beekman and Vautard, 2010) as well as PM projections over heavily populated urban areas. It is plausible that new updated protocols taking into account regional particularities will be implemented in European emission mitigation schemes and more credible assessments could be achieved by incorporating local policy in large-scale inventories. This point is particularly relevant for areas such as Stockholm, where the regional scale mainly drives pollutant concentrations. The transfer of bias from the larger to the finer scale may lead to misclassification of local policy.

Despite the large differences in ozone concentrations simulated at regional and urban scales over the urban area of the city of Paris, rural concentrations are very similar; the projections at both scales show a decrease in ozone at 2050 at comparable magnitudes (Table 6). Therefore, fine-scale information provides little advantage in simulating rural ozone responses in agreement with Markakis et al. (2014). In contrast, PM rural projections are very different between simulations at different resolutions (Table 6) suggesting that regionalscale biases may be transferred to the finer-scale run.

A final remark relates to the relative role of climate change and emissions in future pollutant concentration projections. In contrast to the general conclusion of most recent panEuropean-scale studies (Colette et al., 2013; Geels et al., 2015; Lacressonniere et al., 2014; Langner et al., 2012b) we find that maximum ozone projections over Paris modelled at the urban scale are more sensitive (based on the absolute concentration change from present day) to climate change than to emission mitigation (Sect. 5.3). This suggests that the coarse-resolution applications could overestimate the magnitude of the contribution of the future emissions mitigation to the overall ozone concentration response.

\section{Conclusions}

Long-term projections of air quality at the urban scale integrating local emission policies are scarce. In the present study we investigate mid-21st century ozone and particulate matter concentrations focusing on two European cities: Paris, France and Stockholm, Sweden. Using a fine-resolution modelling system $(4 \mathrm{~km}$ for the IdF region and $1 \mathrm{~km}$ for Stockholm) we quantify the contribution of emission reduction policies and of climate change to pollutant concentration changes at the 2050 horizon. For the Stockholm region we distinguish the role of locally enforced mitigation from that of regional-scale changes in emissions (European policy). Urban-scale emission changes rely on 2030 projections compiled by authorized air quality agencies at Paris and Stockholm. 
The analysis of present-time ozone concentrations reveals very different photochemical conditions in the two case studies; ozone formation in Paris is characterized as VOClimited, with ozone titration being the main driver of concentration levels over the city, while both PM and ozone concentrations in Stockholm depend on long-range transport of pollution (96 and $74 \%$ of the local MD8hr and annual $\mathrm{PM}_{2.5}$ concentrations respectively originate from non-local sources).

Overall we identify an ozone (daily mean and MD8hr) climate benefit up to $-5 \%$ in IdF and $-2 \%$ in Stockholm city despite the overall increase in the mean surface temperatures. For IdF this is not related to changes in local titration (as $\mathrm{NO}_{x}$ concentrations are little affected by 2050) but to changes in the regional climate. Given the dominant regional influence in Stockholm, it is not surprising that the climate change contribution to the final PM concentrations follows the weak trend observed at continental-scale simulations. In IdF, PM concentrations are expected to decrease due to the wetter climate predicted for the region although the trend is very weak.

We find that the mitigation of ozone-precursor emissions implemented in the IdF region instigates spatially irregular ozone concentration changes with a benefit over the rural areas ( -9 and $-12 \%$ for daily mean and MD8hr respectively), while over the urban area we observe a penalty of +8 and $+3 \%$ in daily mean and MD8hr ozone concentrations respectively due to titration inhibition. Under VOC sensitivity ozone benefit may be attained by either pushing NMVOC mitigation over $\mathrm{NO}_{x}$ or by enforcing enough mitigation on $\mathrm{NO}_{x}$ emissions that will allow a shift of the photochemical regime towards $\mathrm{NO}_{x}$-limited conditions prior to 2050 . In contrast, the local emission projection enforces $\mathrm{NO}_{x}$ over NMVOC reductions while, according to the long-term evolution of chemical regimes, studied with the use of chemical regime indicators, $\mathrm{NO}_{x}$ mitigation is not strong enough for the aforementioned shift to take place by 2050 .

In Paris, the increase in the daily mean ozone due to emission changes counterbalances the climate benefit to such an extent that the combined effect is an overall penalty of $+2 \%$. In contrast, changes in MD8hr concentrations due to climate $\left(\Delta c=-4.1 \mu \mathrm{g} \mathrm{m}^{-3}\right)$ are larger compared to those introduced by emission abatement $\left(\Delta c=+2.2 \mu \mathrm{g} \mathrm{m}^{-3}\right)$, indicating that the local maximum is more sensitive to climate change while background ozone concentration levels are more sensitive to emission changes. In Stockholm city and the domain, emission mitigation is largely influential, with reductions several times higher than those introduced by climate both for ozone and PM. Contrary to the Paris case, we show that this response is entirely attributed to changes at the regional scale. Finally, the cumulative effect of climate and emissions in the city of Paris reaches $+2.3 \%$ for daily mean ozone, $-2.4 \%$ for MD8hr ozone, $-33 \%$ for $\mathrm{PM}_{10}$ and $-45 \%$ for $\mathrm{PM}_{2.5}$ while for Stockholm city the figures are $-17 \%$ for daily mean ozone, $-18 \%$ for MD8hr ozone, $-20 \%$ for $\mathrm{PM}_{10}$ and $-20 \%$ for $\mathrm{PM}_{2.5}$.
Another aim of this work was to quantify the plausible added value of the assimilation of local policy into regionalscale inventories. To do so, we compared pollutant concentration changes modelled over the two cities at urban scale against regional-scale simulations over the same areas forced by ECLIPSE, a state-of-the-art emission inventory designed to cope with the drawbacks of inventories such as the RCPs, by assimilating air quality policy at a continental scale. Over Paris the regional-scale simulation is more optimistic than its urban-scale counterpart. The fine-scale modelling yields increase in ozone over the city of Paris (by 8 and 3\% for daily mean and MD8hr respectively) while the regional-scale modelling yields a 7 and $15 \%$ drop respectively. Regionalscale simulations are more optimistic for PM concentrations as well with about $10 \%$ larger reductions compared to the urban-scale projections. These discrepancies are a direct effect of the much stricter mitigation of primary anthropogenic emissions under the ECLIPSE scenario.

Overall our assessment suggests that the long-term evolution of atmospheric pollution solely based on regional-scale emissions may lead to misclassification of the effect. The stricter mitigation in ECLIPSE projections is mainly due to the spatial allocation algorithm, which assigns unrealistically high mitigation over urban areas. It is plausible that new updated protocols taking into account the particularities of regions will be implemented in European emission mitigation schemes and that more credible assessments could be achieved by incorporating local policy to those inventories. An effect, overlooked by the coarse-scale modelling, is the response of MD8hr ozone, a crucial input of health impact assessment studies: for Paris this metric is more responsive to climate change than to emission mitigation.

For Stockholm the comparison of regional- and urbanscale simulations shows small discrepancies given the major role of long-range transport over the area. This stresses the need to better understand the mechanism of bias propagation across the modelling scales in order to design more successful local-scale strategies.

Acknowledgements. This work was carried out within the ACCEPTED project, which is supported by the ERA-ENVHEALTH network (grant agreement no. 219337), with funding from ANSES, ADEME, BelSPO, UBA and the Swedish EPA. Part of the work was also funded by the European Union Seventh Framework Programme (FP7/2007-2013) under the project 760 IMPACT2C: Quantifying projected impacts under $2{ }^{\circ} \mathrm{C}$ warming, grant agreement no. 282746. The ECLIPSE emissions used in this study have been developed by IIASA under the European Commission FP7 project ECLIPSE (Project no. 282688), while additional tasks (development of the MFR scenario) were supported by PEGASOS (Project no. 282688) and "Assessment of hemispheric air pollution on EU air policy" (contract no.07.0307/2011/605671/SER/C3).

Edited by: S. E. Pusede 


\section{References}

AIRPARIF: Evaluation Prospective des emissions et des concentrations des pollutants atmospheriques a l'horizon 2020 en IleDe-France - Gain sur les emissions en 2015, available at: http:// www.airparif.asso.fr/_pdf/publications/ppa-rapport-121119.pdf (last access: 30 September 2015), 2012.

Allen, G., Sioutas, C., Koutrakis, P., Reiss, R., Lurmann, F. W., and Roberts, P. T.: Evaluation of the TEOM method for measurement of ambient particulate mass in urban areas, J. Air Waste Manage., 47, 682-689, 1997.

Andersson, C. and Engardt, M.: European ozone in a future climate: Importance of changes in dry deposition and isoprene emissions, J. Geophys. Res., 115, D02303, doi:10.1029/2008JD011690, 2010.

Andersson, C., Langner, J., and Bergström, R.: Interannual variation and trends in air pollution over Europe due to climate variability during 1958-2001 simulated with a regional CTM coupled to the ERA40 reanalysis, Tellus B, 59, 77-98, doi:10.1111/j.16000889.2006.00196.x, 2007.

Andersson, C., Bergström, R., Bennet, C., Robertson, L., Thomas, M., Korhonen, H., Lehtinen, K. E. J., and Kokkola, H.: MATCHSALSA - Multi-scale Atmospheric Transport and CHemistry model coupled to the SALSA aerosol microphysics model Part 1: Model description and evaluation, Geosci. Model Dev., 8, 171-189, doi:10.5194/gmd-8-171-2015, 2015.

Aw, J. and Kleeman, M. J.: Evaluating the first-order effect of intraannual temperature variability on urban air pollution, J. Geophys. Res., 108, 4365, doi:10.1029/2002JD002688, 2003.

Beekmann, M. and Vautard, R.: A modelling study of photochemical regimes over Europe: robustness and variability, Atmos. Chem. Phys., 10, 10067-10084, doi:10.5194/acp-1010067-2010, 2010

Bergström, R., Denier van der Gon, H. A. C., Prévôt, A. S. H., Yttri, K. E., and Simpson, D.: Modelling of organic aerosols over Europe (2002-2007) using a volatility basis set (VBS) framework: application of different assumptions regarding the formation of secondary organic aerosol, Atmos. Chem. Phys., 12, 8499-8527, doi:10.5194/acp-12-8499-2012, 2012.

Bergström, R., Hallquist, M., Simpson, D., Wildt, J., and Mentel, T. F.: Biotic stress: a significant contributor to organic aerosol in Europe?, Atmos. Chem. Phys., 14, 13643-13660, doi:10.5194/acp14-13643-2014, 2014.

Bessagnet, B., Menut, L., Curci, G., Hodzic, A., Guillaume, B., Liousse, C., Moukhtar, S., Pun, B., Seigneur, C., and Schulz, M.: Regional modeling of carbonaceous aerosols over Europe - Focus on Secondary Organic Aerosols, J. Atmos. Chem., 61, 175202, 2009

Butler, T. M., Stock, Z. S., Russo, M. R., Denier van der Gon, H. A. C., and Lawrence, M. G.: Megacity ozone air quality under four alternative future scenarios, Atmos. Chem. Phys., 12, 44134428, doi:10.5194/acp-12-4413-2012, 2012.

Coleman, L., Martin, D., Varghese, S., Jennings, S. G., and O' Dowd, C. D.: Assessment of changing meteorology and emissions on air quality using a regional climate model: Impact on ozone, Atmos. Environ., 69, 198-210, 2014.

Colette, A., Granier, C., Hodnebrog, Ø., Jakobs, H., Maurizi, A., Nyiri, A., Rao, S., Amann, M., Bessagnet, B., D’Angiola, A., Gauss, M., Heyes, C., Klimont, Z., Meleux, F., Memmesheimer, M., Mieville, A., Rouïl, L., Russo, F., Schucht, S., Simpson,
D., Stordal, F., Tampieri, F., and Vrac, M.: Future air quality in Europe: a multi-model assessment of projected exposure to ozone, Atmos. Chem. Phys., 12, 10613-10630, doi:10.5194/acp12-10613-2012, 2012.

Colette, A., Bessagnet, B., Vautard, R., Szopa, S., Rao, S., Schucht, S., Klimont, Z., Menut, L., Clain, G., Meleux, F., Curci, G., and Rouill, L.: European atmosphere in 2050, a regional air quality and climate perspective under CMIP5 scenarios, Atmos. Chem. Phys., 13, 7451-7471, doi:10.5194/acp-13-7451-2013, 2013.

Clarke, L., Edmonds, J., Jacoby, H., Pitcher, H., Reilly, J., and Richels, R.: Scenarios of Greenhouse Gas Emissions and Atmospheric Concentrations. Sub-report 2.1A of Synthesis and Assessment Product 2.1 by the U.S. Climate Change Science Program and the Subcommittee on Global Change Research, Department of Energy, Office of Biological \& Environmental Research, Washington, D.C., USA, 154 pp., 2007.

Dufresne, J.-L., Foujols, M.-A., Denvil, S., Caubel, A., Marti, O., Aumont, O., Balkanski, Y., Bekki, S., Bellenger, H., Benshila, R., Bony, S., Bopp, L., Braconnot, P., Brockmann, P., Cadule, P., Cheruy, F., Codron, F., Cozic, A., Cugnet, D., de Noblet, N., Duvel, J.-P., Ethé, C., Fairhead, L., Fichefet, T., Flavoni, S., Friedlingstein, P., Grandpeix, J.-Y., Guez, L., Guilyardi, E., Hauglustaine, D., Hourdin, F., Idelkadi, A., Ghattas, J., Joussaume, S., Kageyama, M., Krinner, G., Labetoulle, S., Lahellec, A., Lefebvre, M.-P., Lefevre, F., Levy, C., Li, Z. X., Lloyd, J., Lott, J., Madec, G., Mancip, M., Marchand, M., Masson, S., Meurdesoif, Y., Mignot, J., Musat, I., Parouty, S., Polcher, J., Rio, C., Schulz, M., Swingedouw, D., Szopa, S., Talandier, C., Terray, P., Viovy, N., and Vuichard, N.: Climate change projections using the IPSL-CM5 Earth System Model: from CMIP3 to CMIP5, Clim. Dynam., 40, 2123-2165, 2013.

EEA (Environmental Protection Agency): Air quality in Europe 2013 report, available at: http://www.eea.europa.eu/publications/ air-quality-in-europe-2013 (last access: 30 September 2015), 2013.

Engardt, M., Bergstrom, R., and Andersson, C.: Climate and emission changes contributing to changes in near-surface ozone in Europe over the coming decades: Results from model studies, Ambio, 38, 452-458, doi:10.1579/0044-7447-38.8.452, 2009.

GEA: Global Energy Assessment - Toward a Sustainable Future, Cambridge University Press, Cambridge, UK and New York, NY, USA and the International Institute for Applied Systems Analysis, Laxenburg, Austria, 2012.

Geels, C., Andersson, C., Hänninen, O., Lansø, A. S., Schwarze, P. E., Skjøth, C. A., and Brandt, J.: Future Premature Mortality Due to $\mathrm{O}_{3}$, Secondary Inorganic Aerosols and Primary PM in Europe - Sensitivity to Changes in Climate, Anthropogenic Emissions, Population and Building Stock, Int. J. Environ. Res. Public Health, 12, 2837-2869, 2015.

Gidhagen, L., Engardt, M., Lövenheim, B., and Johansson, C.: Modeling effects of climate change on air quality and population exposure in urban planning scenarios, Adv. Meteorol., 2012, 240894, doi:10.1155/2012/240894, 2012.

Guenther, A., Karl, T., Harley, P., Wiedinmyer, C., Palmer, P. I., and Geron, C.: Estimates of global terrestrial isoprene emissions using MEGAN (Model of Emissions of Gases and Aerosols from Nature), Atmos. Chem. Phys., 6, 3181-3210, doi:10.5194/acp-63181-2006, 2006. 
Giorgi, F., Coppola, E., Solmon, F., Mariotti, L., Sylla, M. B., Bi, X., Elguindi, N., Diro, G. T., Nair, V., Giuliani, G., Turuncoglu, U. U., Cozzini, S., Güttler, L., O’Brien, T. A., Tawfik, A. B., Shalaby, A., Zakey, A. S., Steiner, A. L., Stordal, F., Sloan, L. C., and Brankovic, C.: RegCM4: model description and preliminary tests over multiple CORDEX domains, Clim. Res., 52, 7-29, 2012.

Hauglustaine, D. A., Hourdin, F., Jourdain, L., Filiberti, M.-A., Walters, S., Lamarque, J. F., and Holland, E. A.: Interactive chemistry in the Laboratoire de Meteorologie Dynamique general circulation model: Description and background tropospheric chemistry evaluation, J. Geophys. Res., 190, D04314, doi:10.1029/2003JD003957, 2004.

Jacob, D., Petersen, J., Eggert, B., Alias, A., Christensen, O. B., Bouwer, L. M., Braun, A., Colette, A., Déqué, M., Georgievski, G., Georgopoulou, E., Gobiet, A., Menut, L., Nikulin, G., Haensler, A., Hempelmann, N., Jones, C., Keuler, K., Kovats, S., Kroner, N., Kotlarski, S., Kriegsmann, A., Martin, E., van Meijgaard, E., Moseley, C., Pfeifer, S., Preuschmann, S., Radermacher, C., Radtke, K., Rechid, D., Rounsevell, M., Samuelsson, P., Somot, S., Soussana, J.-F., Teichmann, C., Valentini, R., Vautard, R., Weber, B., and Yiou, P.: EUROCORDEX: new high-resolution climate change projections for European impact research, Reg. Environ. Change, 14, 563-578, doi:10.1007/s10113-013-0499-2, 2014.

Jacob, D. J. and Winner, D. A.: Effect of climate change on air quality, Atmos. Environ., 43, 51-63, 2009.

Jerrett, M., Finkelstein, M. M., Brook, J. R., Arain, M.A., Kanaroglou, P., Stieb, D. M., Gilbert, N. L., Verma, D., Finkelstein, N., Chapman, K. R., and Sears, M. R.: A cohort study of trafficrelated air pollution and mortality in Toronto, Ontario, Canada, Environ. Health Persp., 117, 772-777, 2009.

Johnson, C. E., Collins, W. J., Stevenson, D. S., and Derwent, R. G.: The relative roles of climate and emissions changes on future oxidant concentrations, J. Geophys. Res., 104, 18631-18645, 1999.

Kahnert, M.: Variational data analysis of aerosol species in a regional CTM: background error covariance constraint and aerosol optical observation operators, Tellus B, 60, 753-770, 2008.

Katragkou, E., Zanis, P., Kioutsioukis, I., Tegoulias, I., Melas, D., Krüger, B. C., and Coppola, E.: Future climate change impacts on summer surface ozone from regional climate-air quality simulations over Europe, J. Geophys. Res., 116, D22307, doi:10.1029/2011JD015899, 2011.

Ketzel, M., Omstedt, G., and Johansson, C.: Estimation and validation of $\mathrm{PM}_{2.5} / \mathrm{PM}_{10}$ exhaust and non-exhaust emission factors for practical street pollution modeling, Atmos. Environ., 41, 9370-9385, 2007.

Klimont, Z., Kupiainen, K., Heyes, C., Cofala, J., Rafaj, P., Höglund-Isaksson, L., Borken, J., Schöpp, W., Winiwarter, W., Purohit, P., Bertok, I., and Sander, R.: ECLIPSE V4a: global emission data set developed with the GAINS model for the period 2005 to 2050, Key features and principal data sources, available at: http://eccad.sedoo.fr/eccad_extract_interface/JSF/page_ login.jsf (last access: 30 September 2015), 2013.

Lacressonniere, G., Peuch, V.-H., Vautard, R., Arteta, J., Déqué, M., Joly, M., Josse, B., Marécal, V., and Saint-Martin, D.: European air quality in the 2030s and 2050s: Impacts of global regional emission trends and of climate change, Atmos. Environ., 92, 348-358, 2014.
Lamarque, J.-F., Bond, T. C., Eyring, V., Granier, C., Heil, A., Klimont, Z., Lee, D., Liousse, C., Mieville, A., Owen, B., Schultz, M. G., Shindell, D., Smith, S. J., Stehfest, E., Van Aardenne, J., Cooper, O. R., Kainuma, M., Mahowald, N., McConnell, J. R., Naik, V., Riahi, K., and van Vuuren, D. P.: Historical (1850-2000) gridded anthropogenic and biomass burning emissions of reactive gases and aerosols: methodology and application, Atmos. Chem. Phys., 10, 7017-7039, doi:10.5194/acp10-7017-2010, 2010.

Langner, J., Bergström, R., and Pleijel, K.: European scale modeling of sulfur, oxidised nitrogen and photochemical oxidants. Model development and evaluation for the 1994 growing season, Swedish Meteorological and Hydrological Institute, RMK No. 82, $71 \mathrm{pp}$. (with errata), 1998.

Langner, J., Bergström, R., and Foltescu, V.: Impact of climate change on surface ozone and deposition of sulphur and nitrogen in Europe, Atmos. Environ., 39, 1129-1141, 2005.

Langner, J., Engardt, M., Baklanov, A., Christensen, J. H., Gauss, M., Geels, C., Hedegaard, G. B., Nuterman, R., Simpson, D., Soares, J., Sofiev, M., Wind, P., and Zakey, A.: A multi-model study of impacts of climate change on surface ozone in Europe, Atmos. Chem. Phys., 12, 10423-10440, doi:10.5194/acp12-10423-2012, 2012a.

Langner, J., Engardt, M., and Andersson, C.: European summer surface ozone 1990-2100, Atmos. Chem. Phys., 12, 10097-10105, doi:10.5194/acp-12-10097-2012, 2012b.

Lattuati, M.: Contribution a l'etude du bilan de l'ozone tropospherique a l'interface de l'Europe et de l'Atlantique Nord: modelisation lagrangienne et mesures en altitude, $\mathrm{PhD}$ thesis, Universite P. M. Curie, Paris, France, 1997.

Lauwaet, D., Viaene, P., Brisson, E., van Lipzig, N.P.M., van Noije, T., Strunk, A., Van Looy, S., Veldeman, N., Blyth, L., De Ridder, K., and Janssen, S.: The effect of climate change and emission scenarios on ozone concentrations over Belgium: a highresolution model study for policy support, Atmos. Chem. Phys., 14, 5893-5904, doi:10.5194/acp-14-5893-2014, 2014.

Lepeule, J., Laden, F., Dockery, D., and Schwartz, J.: Chronic exposure to fine particles and mortality: an extended follow-up of the Harvard Six Cities study from 1974 to 2009, Environ. Health Persp., 120, 965-970, 2012.

Liao, H., Chen, W.-T., and Seinfeld, J. H.: Role of climate change in global predictions of future tropospheric ozone and aerosols, J. Geophys. Res., 111, D12304, doi:10.1029/2005JD006852, 2006.

Likhvar, V., Pascal, M., Markakis, K., Colette, A., Hauglustaine, D., Valari, M., Klimont, Z., Medina, S., and Kinney, P.: A multi-scale health impact assessment of air pollution over the 21 st century, Sci. Total. Environ., 514, 439-449, 2015.

Markakis, K., Valari, M., Colette, A., Sanchez, O., Perrussel, O., Honore, C., Vautard, R., Klimont, Z., and Rao, S.: Air quality in the mid-21st century for the city of Paris under two climate scenarios; from the regional to local scale, Atmos. Chem. Phys., 14, 7323-7340, doi:10.5194/acp-14-7323-2014, 2014.

Markakis, K., Valari, M., Perrussel, O., Sanchez, O., and Honore, C.: Climate-forced air-quality modeling at the urban scale: sensitivity to model resolution, emissions and meteorology, Atmos. Chem. Phys., 15, 7703-7723, doi:10.5194/acp-15-7703-2015, 2015 . 
Megaritis, A. G., Fountoukis, C., Charalampidis, P. E., Denier van der Gon, H. A. C., Pilinis, C., and Pandis, S. N.: Linking climate and air quality over Europe: effects of meteorology on $\mathrm{PM}_{2.5}$ concentrations, Atmos. Chem. Phys., 14, 10283-10298, doi:10.5194/acp-14-10283-2014, 2014.

Menut, L., Schmechtig, C., and Marticorena, B.: Sensitivity of the sandblasting fluxes calculations to the soil size distribution accuracy, J. Atmos. Ocean. Tech., 22, 1875-1884, 2005.

Menut, L., Bessagnet, B., Khvorostyanov, D., Beekmann, M., Blond, N., Colette, A., Coll, I., Curci, G., Foret, G., Hodzic, A., Mailler, S., Meleux, F., Monge, J.-L., Pison, I., Siour, G., Turquety, S., Valari, M., Vautard, R., and Vivanco, M. G.: CHIMERE 2013: a model for regional atmospheric composition modelling, Geosci. Model Dev., 6, 981-1028, doi:10.5194/gmd6-981-2013, 2013.

Nenes, A., Pilinis, C., and Pandis, S.: ISORROPIA: A new thermodynamic model for inorganic multicomponent atmospheric aerosols, Aquat. Geochem., 4, 123-152, 1998.

Nolte, C. G., Gilliland, A. B., Hogrefe, C., and Mickley, L. J.: Linking global to regional models to assess future climate impacts on surface ozone levels in the United States, J. Geophys. Res., 113, D14307, doi:10.1029/2007JD008497, 2008.

Omstedt, G., Bringfelt, B., and Johansson, C.: A model for vehicleinduced non-tailpipe emissions of particles along Swedish roads, Atmos. Environ., 39, 6088-6097, 2005.

Pascal, M., Corso, M., Chanel, O., Declecq, C., Badaloni, C., Cesaroni, G., Henschel, S., Maister, K., Haluza, D., Martin-Olmedo, P., and Medina S.: Assessing the public health impact of urban air pollution in 25 European cities: results of the Aphekom project, Sci. Total Environ., 449, 390-400, 2013.

Prather, M., Gauss, M., Berntsen, T., Isaksen, I., Sundet, J., Bey, I., Brasseur, G., Dentener, F., Derwent, R., Stevenson, D., Grenfell, L., Hauglustaine, D., Horowitz, L., Jacob, D., Mickley, L., Lawrence, M., von Kuhlmann, R., Muller, J.-F., Pitari, G., Rogers, H., Johnson, M., van Weele, M., and Wild, O.: Fresh air in the 21st century?, Geophys. Res. Lett., 30, 1100, doi:10.1029/2002GL016285, 2003.

REVIHAAP: Review of evidence on health aspects of air pollution - REVIHAAP Project, available at: http://www.euro.who.int/en/health-topics/environment-andhealth/air-quality/publications/2013/review-of-evidence-onhealth-aspects-of-air-pollution-revihaap-project-final-technicalreport (last access: 30 September 2015), 2013.

Riahi, K., Rao, S., Krey, V., Cho, C., Chirkov, V., Fischer, G., Kindermann, G., Nakicenovic, N., and Rafaj, P.: RCP 8.5-A scenario of comparatively high greenhouse gas emissions, Climatic Change, 109, 33-57, 2011.

Robertson, L., Langner, J., and Engardt, M.: An Eulerian limitedarea atmospheric transport model, J. Appl. Meteorol., 38, 190210,1999

Seinfeld, J. H. and Pandis, S. N.: Atmospheric Chemistry and Physics: From Air Pollution to Climate Change, 2nd Edn., John Wiley and Sons, Hoboken, NJ, 2006.

Skamarock, W. C. and Klemp, J. B.: A time-split non-hydrostatic atmospheric model, J. Comput. Phys., 227, 3465-3485, 2008.

Sillman, S. and He, D.: Some theoretical results concerning O3NOx-VOC chemistry and NOx-VOC indicators, J. Geophys. Res., 107, 4659, doi:10.1029/2001JD001123, 2002.
Sillman, S., Vautard, R., Menut, L., and Kley, D.: O3-NOXVOC sensitivity and NOX-VOC indicators in Paris: Results from models and Atmospheric Pollution over the Paris Area (ESQUIF) measurements, J. Geophys. Res., 108, 8563, doi:10.1029/2002JD001561, 2003.

Simpson, D., Benedictow, A., Berge, H., Bergström, R., Emberson, L. D., Fagerli, H., Flechard, C. R., Hayman, G. D., Gauss, M., Jonson, J. E., Jenkin, M. E., Nyíri, A., Richter, C., Semeena, V. S., Tsyro, S., Tuovinen, J.-P., Valdebenito, Á., and Wind, P.: The EMEP MSC-W chemical transport model - technical description, Atmos. Chem. Phys., 12, 7825-7865, doi:10.5194/acp-127825-2012, 2012.

Sjödin, A., Ekström, M., and Hammarström, U.: Implementation and Evaluation of the ARTEMIS Road Model for Sweden's International Reporting Obligations on Air Emissions, in Proceedings of the 2nd Conference Environment \& Transport including the 15th Conference of Transport \& Air Pollution, Vol. 1, 375382, Reims, France, June 2006.

Strandberg, G., Bärring, L., Hansson, U., Jansson, C., Jones, C. Kjellström, E., Kolax, M., Kupiainen, M., Nikulin, G., Samuelsson, P., Ullerstig, A., and Wang, S.: CORDEX scenarios for Europe from the Rossby Centre regional climate model RCA4. SMHI reports, RMK 116. ISSN 0347-2116, 2014.

Szopa, S. and Hauglustaine, D.: Relative impacts of worldwide tropospheric ozone changes and regional emission modifications on European surface-ozone levels, C. R. Geosci., 339, 709-720, 2007.

Szopa, S., Balkanski, Y., Schulz, M., Bekki, S., Cugnet, D., Fortems-Cheiney, A., Turquety, S., Cozic, A., Deandreis, C., Hauglustaine, D., Idelkadi, A., Lathiere, J., Lefevre, F., Marchand, M., Vuolo, R., Yan, N., and Dufresne, J.-L.: Aerosol and ozone changes as forcing for climate evolution between 1850 and 2100, Clim. Dynam., 40, 2223-2250, 2013.

Valari, M. and Menut, L.: Does an Increase in Air Quality Models' Resolution Bring Surface Ozone Concentrations Closer to Reality?, J. Atmos. Ocean. Tech., 25, 1955-1968, 2008.

Vautard, R., Honoré, C., Beekmann, M., and Rouil, L.: Simulation of ozone during the August 2003 heat wave and emission control scenarios, Atmos. Environ., 39, 2957-2967, 2005.

Vautard R., Builtjes, P. H. J., Thunis, P., Cuvelier, C., Bedogni, M., Bessagnet, B., Honore, C., Moussiopoulos, N., Pirovano, G., Schaap, M., Stern, R., Tarasson, L., and Wind, P.: Evaluation and intercomparison of Ozone and $\mathrm{PM}_{10}$ simulations by several chemistry transport models over four European cities within the CityDelta project, Atmos. Environ., 41, 173-188, 2007.

Vautard, R., Gobiet, A., Sobolowski, S., Kjellström, E., Stegehuis, A., Watkiss, P., Mendlik, T., Landgren, O., Nikulin, G., Teichmann, C., and Jacob, D.: The European climate under a $2{ }^{\circ} \mathrm{C}$ global warming, Environ. Res. Lett., 9, 034006, doi:10.1088/1748-9326/9/3/034006, 2014.

Watson, L., Lacressonnière, G., Gauss, M., Engardt, M., Andersson, C., Josse, B., Marécal, V., Nyiri, A., Sobolowski, S., Siour, G., and Vautard, R.: The impact of meteorological forcings on gas phase air pollutants over Europe, Atmos. Environ., 119, 240 $257,2015$. 
Yttri, K. E., Simpson, D., Nøjgaard, J. K., Kristensen, K., Genberg, J., Stenström, K., Swietlicki, E., Hillamo, R., Aurela, M., Bauer, H., Offenberg, J. H., Jaoui, M., Dye, C., Eckhardt, S., Burkhart, J. F., Stohl, A., and Glasius, M.: Source apportionment of the summer time carbonaceous aerosol at Nordic rural background sites, Atmos. Chem. Phys., 11, 13339-13357, doi:10.5194/acp11-13339-2011, 2011.
Zanis, P., Katragkou, E., Tegoulias, I., Poupkou, A., Melas, D., Huszar, P., and Giorgi, F.: Evaluation of near surface ozone in air quality simulations forced by a regional climate model over Europe for the period 1991-2000, Atmos. Environ., 45, 64896500, 2011. 